\title{
Paleocene echinoid faunas of the eastern United States
}

\author{
Louis G. Zachos \\ Department of Geology and Geological Engineering, 118G Carrier Hall, University of Mississippi, University, MS 38677〈lgzachos@olemiss.edu〉
}

\begin{abstract}
Twenty-one species of echinoid are reported from Paleocene rocks of the eastern United States along the outcrop belt from Texas to New Jersey. Six of these are strictly early Paleocene age (Danian), nine strictly late Paleocene age (Thanetian), five range throughout the Paleocene, and one previously reported Paleocene species (Diplodetus moscovensis) is most likely a Cretaceous species. Two new species are described, Salenia palmyra n. sp., from the Danian Clayton Formation in Alabama and Georgia, and Ova rancoca n. sp., from the Thanetian Vincentown Formation in New Jersey. One new species from the Clayton Formation in Mississippi, Arbaciella? sp., is left in open nomenclature.
\end{abstract}

\section{Introduction}

Sedimentary rocks of Paleocene age are exposed in the eastern United States in the Atlantic Coastal Plain from New Jersey to South Carolina, and the Gulf of Mexico Coastal Plain from Georgia through Texas (Fig. 1). Unfortunately, the spottiness of unweathered Paleocene outcrops throughout this region, the wide range in lithologies (and associated paleoecologies), and the relatively poor collection record have resulted in the lack of comprehensive studies of the macrofaunas of these deposits. This is particularly true of the echinoid faunas.

The Paleocene was a period of transition in echinoid faunas, with retention of a distinctly Cretaceous character and only a few tantalizing glimpses of the genera that came to dominate the remaining Cenozoic. Only the echinoid fauna of the late Paleocene (Thanetian) Vincentown Formation of New Jersey (Fig. 2) has been fairly well known until now, and it has long been recognized as more closely resembling the faunas of the Late Cretaceous than those of the post-Paleocene Cenozoic (Cooke, 1959). This study, following new collection, curation, and taxonomic re-evaluation of Paleocene echinoids from the Gulf of Mexico Coastal Plain as well as additional material from the Vincentown Formation, is a comprehensive look at their diversity and general biogeography within the eastern United States.

The Paleocene echinoids of the Gulf Coast are a more diverse group than previously documented, with cidaroids, salenioids, temnopleuroids, phymosomatoids, arbacioids, holasteroids, cassiduloids, and spatangoids. No evidence of clypeasteroids has been found in any Gulf Coast sediments older than Ypresian (early Eocene). The 21 species of echinoids reported in this study are distributed unequally in the Paleoceneage rocks of the eastern United States (Fig. 3). Six of these are strictly early Paleocene age (Danian), nine strictly late Paleocene age (Thanetian), five range throughout the Paleocene (one of these, Plagiochasma cruciferum, possibly ranging from the Late Cretaceous of Delaware), and one previously reported Paleocene species (Diplodetus moscovensis) is most likely a strictly Cretaceous species.
None of the 21 listed species ranges into sediments younger than Paleocene. Only four nominal species of early Eocene (Ypresian) echinoids are known from the eastern United States. These include an unidentified hemiasterid from the Nanjemoy Formation, Evergreen, Prince George County, Virginia (Zachos and Levin, 2010), Linthia hollandi Barry (in Barry and Le Blanc, 1942) from the Sabinetown Formation, Pendleton Bluff, Sabine County, Texas, Eurhodia elbana Cooke, 1942, and Fibularia texana (Twitchell, in Clark and Twitchell, 1915), both from the Bashi Formation, below the dam south of Elba on the Pea River, Coffee County, Alabama. This abrupt loss of diversity and turnover in the echinoid genera and species coincides with the Paleocene/Eocene Thermal Maximum (Zachos, et al., 2001). Echinoid diversity increased during the middle and late Eocene (Lutetian, Bartonian, and Priabonian) in the region, marking the recovery of echinoid faunas following this significant climatic event and the loss of many of the holdover genera of the Cretaceous.

\section{Geologic setting}

Paleocene sediments are exposed in a narrow belt from New Jersey into northern Virginia (Fig. 1), but with only a few scattered outcrops in North and South Carolina. In the Gulf of Mexico coastal plain there is a nearly continuous outcrop belt of Paleocene deposits stretching $2000 \mathrm{~km}$. from southwestern Georgia to the Rio Grande in Texas (and continuing into Mexico). The stratigraphic correlation of Paleocene formations along this outcrop belt is shown in Figure 2. The Atlantic Coastal Plain deposits are primarily siliciclastic and glauconite rich, although the echinoid-bearing portion of the Vincentown Formation is calcareous. The lowermost Paleocene deposits in the eastern Gulf of Mexico Coastal Plain are calcareous, but clays are predominant in the upper portion. The calcareous beds thin considerably into the Mississippi Embayment region but are found on both the Mississippi and Arkansas sides of the embayment, grading northward into siliciclastic marine beds that extend into southern Illinois (Cope et al., 2005). Except for 


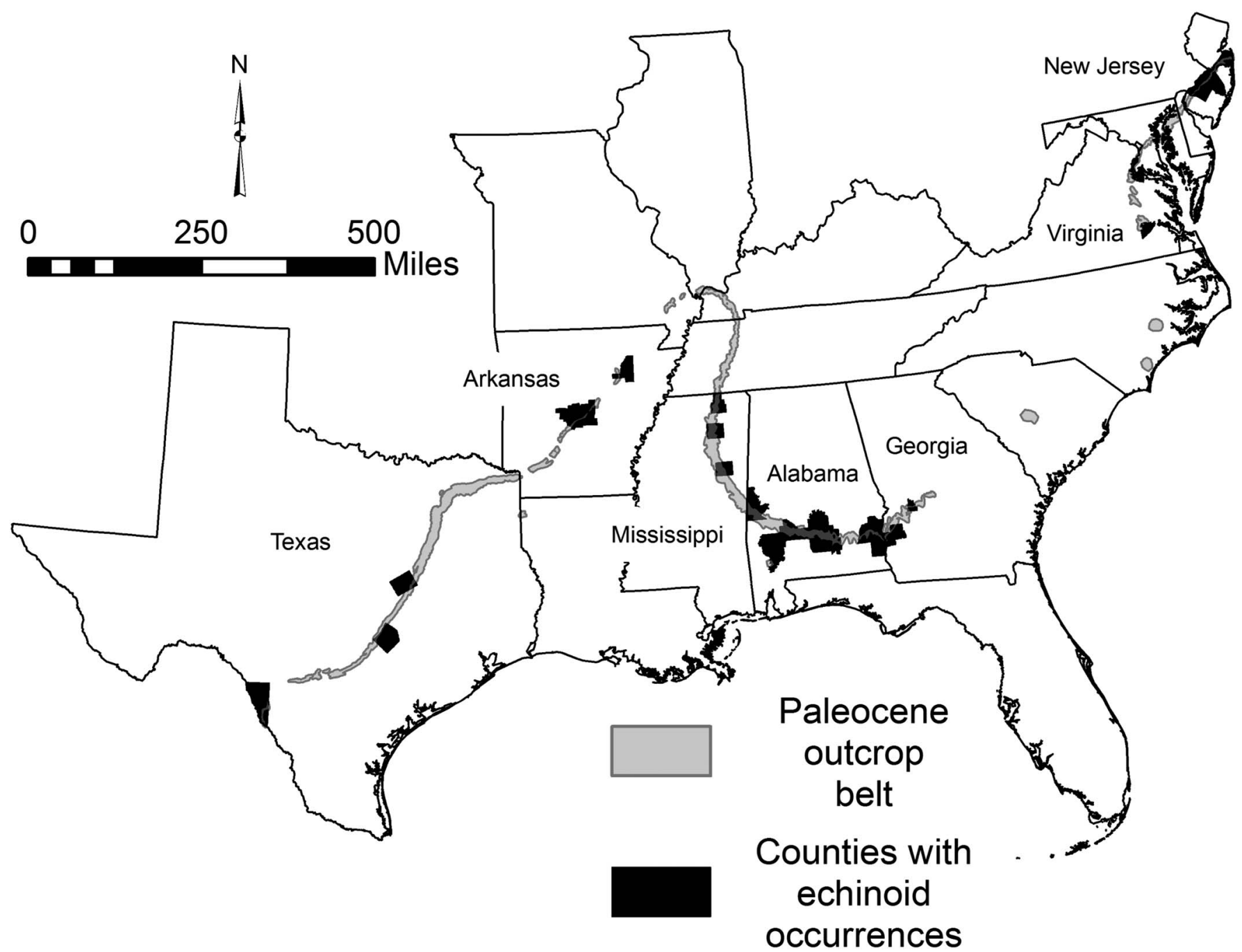

Figure 1. Outcrop belt of Paleocene sediments (light shading). Echinoid fossils (fragmentary in some cases) have been found in counties indicated by dark fill.

a calcareous unit (Tehuacana Limestone, Danian) localized in Falls and Limestone counties, the Paleocene is primarily a siliciclastic unit in central Texas, becoming more calcareous near the border with Mexico (Gardner, 1933).

In New Jersey, Paleocene echinoids are known only from the Vincentown Formation (Cooke, 1959). The age of the Vincentown Formation, based on calcareous nannoplankton, ranges from Zone NP5 to NP9 (Bybell, 1992), or Selandian to Thanetian (Berggren and Pearson, 2005). The calcareous facies of the Vincentown is echinoid-bearing. This facies is bioclastic and composed primarily of bryozoan and other skeletal debris. Echinoid spines are known from the calcareous glauconitic sands of the Aquia Formation (also Thanetian in age) of Virginia and possibly Maryland (Zachos and Levin, 2010).

The global Paleocene Series stages (Danian, Selandian, and Thanetian) are all represented in the Gulf of Mexico Coastal Plain by the Midway group and lower part of the Wilcox Group. The Midway Group comprises predominantly marine deposits. The upper units become progressively more terrigenous in character in the western Gulf of Mexico region, where they are overlapped by the deltaic sands of the Wilcox Group of late Paleocene (Thanetian) and early Eocene (Ypresian) age
(Davidoff and Yancey, 1993). In the eastern Gulf of Mexico region, the Wilcox Group is more commonly represented by marginal-marine deposits. In southwestern Georgia and southern Alabama echinoids are common in the calcareous portions of the Clayton Formation, which ranges from Zone NP1 to NP2 (Danian). The Clayton is characteristically a coarse bioclastic limestone composed of bryozoan, algal, and other skeletal debris in Georgia and eastern Alabama; a fine-grained, somewhat chalky limestone in central Alabama; and a mix of calcareous glauconitic sand, sandy bioclastic limestone, and fine-grained clayey limestone in northern Mississippi and eastern Arkansas. There are some unconfirmed reports of echinoid occurrences in the argillaceous Porters Creek Formation, Zone NP3 to NP4 (Danian-Selandian) (Mancini and Tew, 1991). The echinoidbearing but isolated and fault-bound Salt Mountain Limestone outcrop in Alabama is correlated with the Nanafalia Formation, Zone NP5 through NP8 (Selandian-Thanetian) and roughly equivalent to the Vincentown Formation. The Salt Mountain Limestone is predominantly a dense, chalky, coralline limestone, coarser near the exposed base where it grades into a bioclastic limestone with algal, foraminiferal, and echinoderm skeletal debris. Disarticulated echinoid plates and spines are ubiquitous 


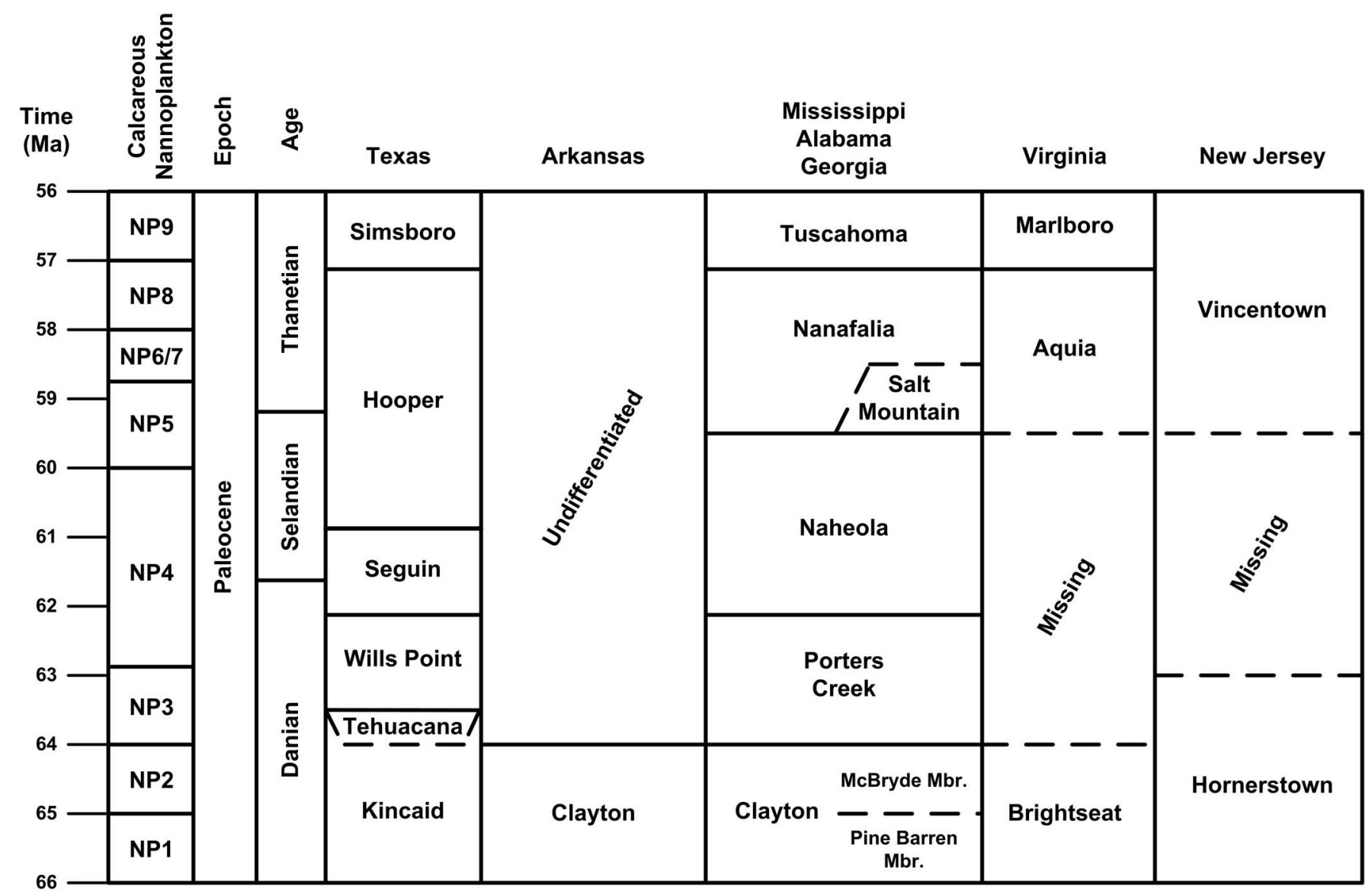

Figure 2. Generalized stratigraphic nomenclature of the Paleocene section in the eastern United States. Absolute dates from Walker et al. (2012). Stratigraphic correlations modified from Ward and Powars (1989) and Martínez-Díaz et al. (2016).

in calcareous portions of the Clayton Formation in northern Mississippi, and complete material has been collected from the Clayton Formation in Arkansas. In Texas, the argillaceous lower Kincaid Formation, ranging from Zone NP1 to NP2 (Danian), is the source of a single echinoid specimen, but its calcareous facies, the Tehuacana Limestone, which is correlated with Zone NP3 (Davidoff and Yancey, 1993), contains rare entire tests and uncommon disarticulated echinoid plates and spines. The glauconitic sand of the Wills Point Formation (Danian) is the source of a few very fragile echinoids in central Texas. These latter specimens are interesting because they retain the original high-magnesium calcite and stereom structure of the original test (Zachos, 2008).

\section{Materials and methods}

Repositories and institutional abbreviations.-The repositories of type and figured material are indicated by the following abbreviations: AMNH, American Museum of Natural History, New York, NY; ANSP, Academy of Natural Sciences of Drexel University, Philadelphia, PA; MMNS, Mississippi Museum of Natural Science, Jackson, MS; HMCZ, Harvard Museum of Comparative Zoology, Cambridge, Massachusetts; NHM, Natural History Museum, London, UK; NPL, Non-vertebrate Paleontology Laboratory, The University of Texas at Austin, Austin, TX; UF, Florida Museum of Natural History, University of Florida, Gainesville, FL; USNM, U.S. National Museum of Natural History, Washington, DC.

Localities for the Vincentown collections from New Jersey were listed by Clark and Twitchell (1915) and Cooke (1959). Localities for the Aquia collections from Virginia were given by Zachos and Levin (2010). Many Paleocene localities in Alabama and Georgia were listed by Toulmin (1977), which is one of the better sources for locations in the eastern Gulf of Mexico Coastal Plain. New locality information from this study is included with individual species descriptions.

\section{Systematic paleontology}

Order Cidaroida Claus, 1880

Family Cidaridae Gray, 1825

Subfamily Cidarinae Mortensen, 1928

Genus Cidaris Leske, 1778

Cidaris splendens (Morton, 1841)

Figure 4.1-4.3

1841 Cidarites splendeus Morton, p. 132. Typographical error for splendens.

1842 Cidarites armiger Morton, p. 215, pl. 11, fig. 1.

1893 Cidaris splendens; Clark, p. 33, pl. 6, figs. 3a-g.

1907 Cidaris splendens; Weller, p. 279, pl. 7, figs. 1-9. 


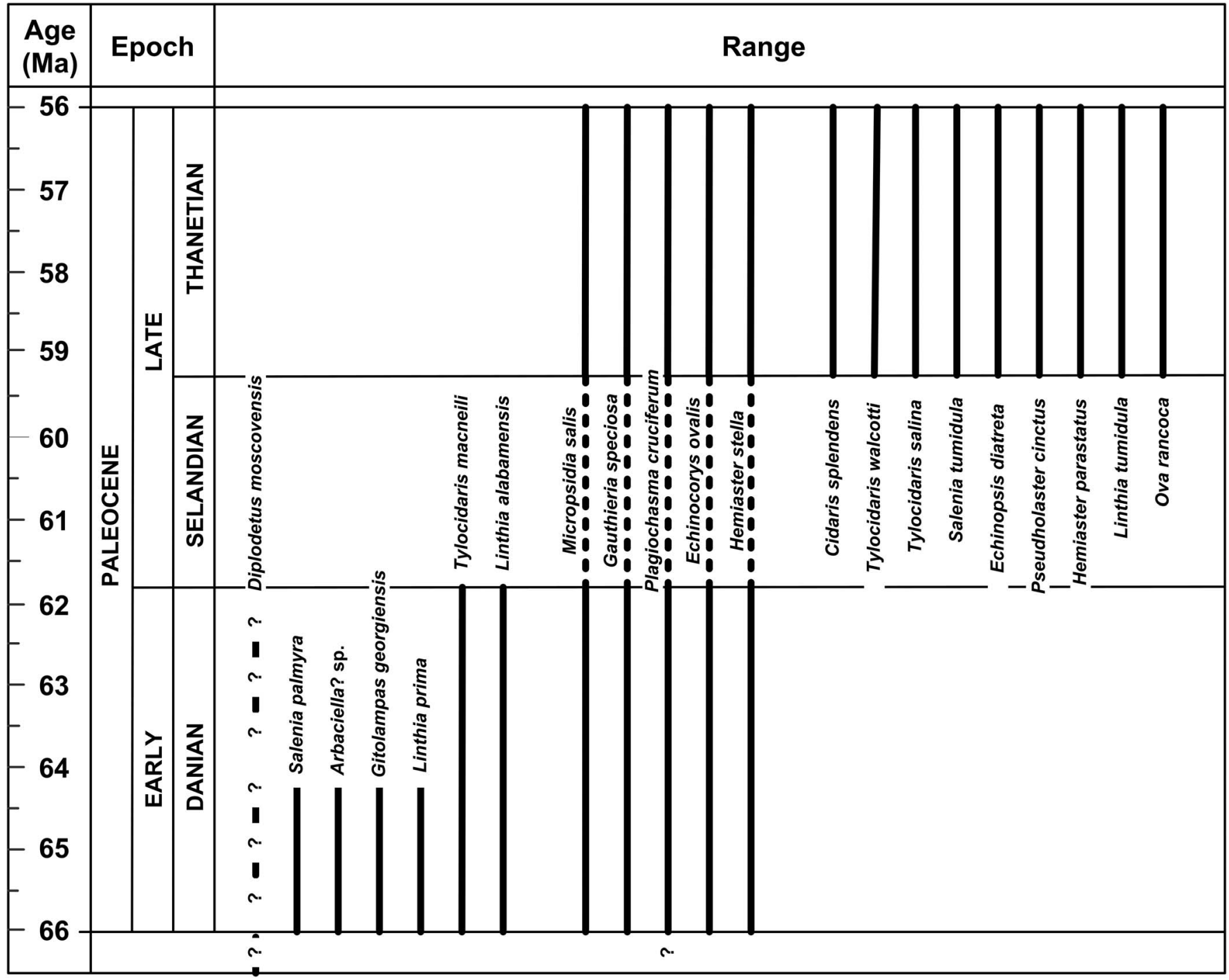

Figure 3. Chronologic ranges of Paleocene echinoid taxa from the eastern United States. Absolute dates from Walker et al. (2012). Ranges are dashed across the Selandian Stage because no echinoid occurrences have been confidently reported from rocks of this age (exposures of which are almost entirely non-marine) in the eastern United States.

1915 Cidaris splendens; Clark in Clark and Twitchell, p. 46, pl. 9, figs. 4a, b, 5a-f, 6 .

1941 Cidaris splendens (Morton) part; Cooke, p. 5.

1959 Cidaris splendens; Cooke, p. 9, pl. 1, fig. 10.

1959 Cidaris sp. aff. C. splendens; Cooke, p. 10, pl. 1, fig. 11 .

1977 Cidaris splendens; Toulmin, p. 177, pl. 9, fig. 4.

1997 Cidaris sp. Carter, p. 47, pl. 1, figs. 1a-c, 2.

2000 Cidaris splendens; Smith and Jeffery, p. 36, text-fig. $12 \mathrm{e}, \mathrm{f}$.
Types.-Holotype ANSP 1454, from the Vincentown Formation, Timber Creek, New Jersey.

Description.-Five or six large interambulacral plates per column. Large, perforate, primary tubercles set in wide, circular areoles. Narrow adradial and interradial zones with small granules. Single series of equant, round pores in each ambulacral column; plating simple. Primary spines long, cylindrical with labyrinthine core and outer cortex, and serrated ribs.

Figure 4. Cidaris splendens (Morton, 1841) from the Salt Mountain Limestone, Salt Mountain, Clarke County, AL: (1) MMNS 4895, portion of interambulacrum; (2) MMNS 5132.1, crushed test; (3) MMNS 5132.2, primary tubercle. Tylocidaris macneili Cooke, 1959 from the Clayton Formation, Henry County, AL: (4) USNM 565262a, portion of interambulacrum; (5) USNM 562262b, spine; (6) USNM 562262c, spine. Tylocidaris walcotti (Clark, 1891) from the Vincentown Formation, Blackwoodstown, NJ: (7), USNM 18828, spine. Tylocidaris salina Cooke, 1959 from the Salt Mountain Limestone, Salt Mountain, Clarke County, AL: (8) MMNS 4882, spine. Salenia tumidula Clark, 1891 from the Vincentown Formation, Vincentown, Burlington County, NJ: (9) USNM 540892, aboral; (12) USNM 540892, oral. Salenia palmyra n. sp. from the Clayton Formation, Palmyra tract, Lowndes County, AL: (10) MMNS 7097, paratype, aboral; (11) MMNS 7099, holotype, aboral; (13) MMNS 7099, holotype, profile; (14) MMNS 7099, holotype, oral. Scale bars are (1, 3, 5-14) $5 \mathrm{~mm}$; (4) $2 \mathrm{~mm}$; (2) $10 \mathrm{~mm}$. 

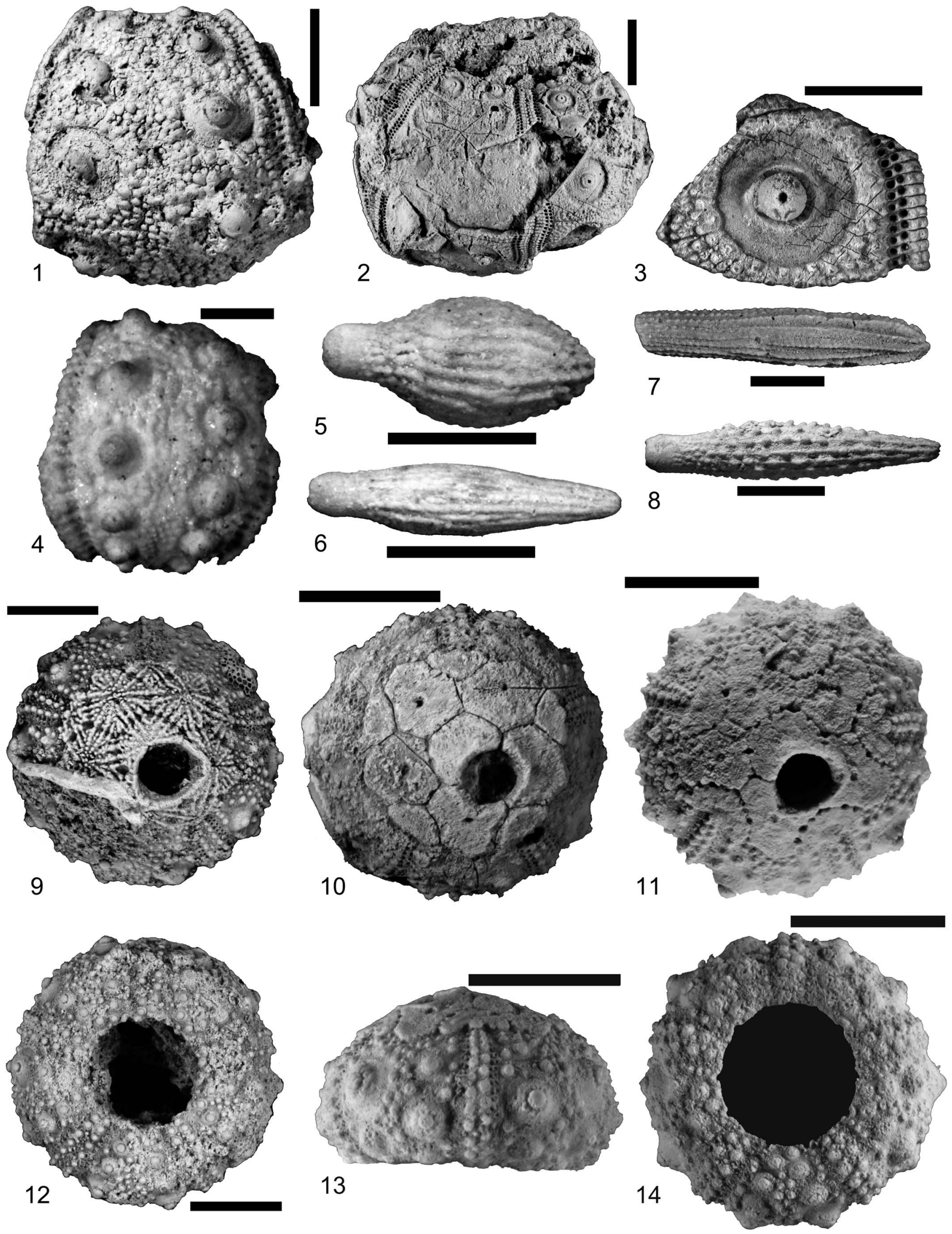
Additional material.-USNM 559497, figured by Clark (in Clark and Twitchell, 1915), from the Vincentown Formation; USNM 498879a, figured by Cooke (1959) as Cidaris sp. aff. C. splendens and MMNS 5132, both from the Salt Mountain Limestone, Clarke County, Alabama.

Occurrence.-Vincentown Formation, Timber Creek, Gloucester County, New Jersey (exact locality unknown); Vincentown, Burlington County, New Jersey (UTM Zone 18, E 520,995 m, N 4,421,446 m, NAD83). Salt Mountain Limestone, Salt Mountain, Clarke County, Alabama (UTM Zone 16, E 417,423 m, N 3,478,716 m, NAD83).

Remarks.-Description is based on the original published description. Morton (1842, p. 215) indicated that $C$. armiger was to replace the name for the same specimen named C. splendens the prior year (Morton, 1841), thus C. armiger is an objective junior synonym. Because fossil Cidaris, when known only from fragmentary material, are impossible to confidently identify to species level, all finds attributable to this genus have been lumped into this nominal species. Fragments of the test are fairly common at Salt Mountain, Alabama.

Family Psychocidaridae Ikeda, 1936

Genus Tylocidaris Pomel, 1883

Tylocidaris walcotti (Clark, 1891)

Figure 4.7

1891 Cidaris walcotti Clark, p. 75.

1893 Cidaris walcotti; Clark, p. 37, pl. 6, figs. 4a-d.

1907 Cidaris walcotti; Weller, p. 281, pl. 7, figs. 10-13.

1915 Cidaris walcotti; Clark in Clark and Twitchell, p. 45, pl. 9, figs. 3a-d.

1925 Cidaris walcotti; Lambert and Thiéry, p. 559.

1941 Tylocidaris walcotti; Cooke, p. 6.

1959 Tylocidaris walcotti; Cooke, p. 12, pl. 1, figs. 7-9.

2000 Tylocidaris sp. indet. Smith and Jeffery, p. 14.

Types.-Holotype ANSP 1451, from the Vincentown Formation, Timber Creek, New Jersey.

Description.-Test small. Ambulacra narrow. Primary tubercles imperforate, set in medium, smooth areoles, separated, much of interambulacral plates covered in small, equally sized granules. Ambulacral plating simple. Spines fusiform, ribbed, thorned.

Additional material.-USNM 18828, figured by Cooke (1959) and USNM 648534, both from the Vincentown Formation, Blackwoodstown, New Jersey (exact locality unknown).

Occurrence.-Vincentown Formation, Timber Creek and Blackwoodstown, Camden County, New Jersey (exact localities unknown).

Remarks.-Description is based on the original published description. Smith and Jeffery (2000) singled out this species as indeterminate, but this does not invalidate the name.
All fragmentary material attributable to Tylocidaris from the Vincentown Formation is here assigned to this nominal species.

Tylocidaris macneili Cooke, 1959

Figure 4.4-4.6

1959 Tylocidaris macneili Cooke, p. 12, pl. 1, figs. 3-5.

Types.-Holotype USNM 562262a, paratypes (spines) USNM 563362 b, c. All from the Clayton Formation, Henry County, Alabama.

Description.-Test small. Ambulacra narrow, plating simple. Primary tubercles imperforate, set in medium, smooth areoles, separated, much of interambulacral plates covered in small, equally sized granules. Spines fusiform, nodose, ribbed, ribs discontinuous and convergent towards tip, finely toothed.

Occurrence.-Clayton Formation, Henry County, Alabama (UTM Zone 16, E 671,3565 m, N 3,509,113 m, NAD83).

Remarks.-Description is based on the original description. Only known with certainty from this one locality, but all strongly nodose spines from the Clayton Formation are here attributed to this nominal species. Smith and Jeffery (2000) synonymized this species with $T$. hardouini (Desor, 1858), a species based entirely on spines with a distinctly clavate or club-like shape, but the spines of $T$. macneili are significantly different, being much more fusiform than clavate.

Tylocidaris salina Cooke, 1959

Figure 4.8

1941 Cidaris splendens (Morton) part, Cooke, p. 5, pl. 1, figs. 13-15.

1959 Tylocidaris? salina Cooke, p. 12, pl. 1, figs. 12-14.

2000 Tylocidaris salina; Smith and Jeffery, p. 39.

Types.-Holotype USNM 498879b, from the Salt Mountain Limestone, Salt Mountain, Clarke County, Alabama.

Description.-Spines fusiform, straight-ribbed, with smooth, regular beads ornamenting the ribs.

Additional material.-USNM 648529, USNM 648530, USNM 648531, and MMNS 4882, all from the Salt Mountain Limestone, Salt Mountain, Clarke County, Alabama.

Occurrence.-Salt Mountain Limestone, Salt Mountain, Clarke County, Alabama (UTM Zone 16, E 417,423 m, N 3,478,716 m, NAD83).

Remarks.-Description is based on the original published description. The spines of $T$. salina can be distinguished from $T$. walcotti by their straight, non-convergent ribs and smooth beading.

Order Salenioida Delage and Hérouard, 1903

Family Saleniidae Agassiz, 1838

Subfamily Saleniinae Agassiz, 1838 
Genus Salenia Gray, 1835

Salenia tumidula Clark, 1891

Figure 4.9, 4.12

1891 Salenia tumidula Clark, p. 75.

1891 Salenia bellula Clark, p. 75.

1893 Salenia tumidula; Clark, p. 41, pl. 11, figs. 1a-j.

1893 Salenia bellula; Clark, p. 41, pl. 11, figs. 2a-g.

1907 Salenia tumidula; Weller, p. 282, pl. 8, figs. 1-10.

1907 Salenia bellula; Weller, p. 282, pl. 8, figs. 11-17.

1915 Salenia tumidula; Clark in Clark and Twitchell, p. 50, pl. 13, figs. 1a-j.

1915 Salenia bellula; Clark in Clark and Twitchell, p. 50, pl. 13, figs. 2a-g.

1941 Salenia tumidula; Cooke, p. 7.

1941 Salenia bellula; Cooke, p. 7.

1959 Salenia tumidula; Cooke, p. 13, pl. 2, figs. 1-7.

2000 Salenia (Salenia) tumidula; Smith and Jeffery, p. 51, text-fig. 18.

Types.-Holotype ANSP 1448 and paratype ANSP 1446 (type of $S$. bellula) from the Vincentown Formation, Timber Creek near Vincentown, New Jersey.

Description.-Test small, slightly rounded above and flattened aborally. Apical disc rounded, $\sim 70 \%$ of test diameter, low in profile. Small but distinct pits along genital-genital and genitalocular plate sutures. All apical disc plates with a characteristic radial pattern of granules. Periproct subtrigonal, at juncture of genital plates 1 and 5 and suranal plate. Ambulacra strictly bigeminate with hardly any pore crowding adorally. Columns of primary ambulacral tubercles separated by about the diameter of one tubercle; secondary tubercles discernible perradially. Interambulacra with five or six plates in a column. Interradial zone narrow with few granules outside the scrobicular ring. Peristome $\sim 40 \%$ of test diameter, weakly notched.

Occurrence.-Vincentown Formation, Timber Creek near Vincentown (exact locality unknown). Other localities in New Jersey were listed by (Cooke, 1959).

Remarks.-Description is based on the original published description. The stellate patterns of granules on the apical disc plates are distinctive and clearly differentiate $S$. tumidula from other Paleocene species. Cooke (1941) remarked that $S$. tumidula and S. bellula, the latter not seen by him but judged from published figures, did not seem to be convincingly different. Cooke (1959), after study of types of both species, synonymized them. There are a number of specimens across a range of sizes in the USNM collection showing gradation in the ornamentation of the plates of the apical disc, the main character originally used to distinguish the two species, and this synonymy is accepted here. Clark's (1891) description of S. tumidula appears one paragraph before $S$. bellula and so has priority.

Salenia palmyra new species

Figure 4.10, 4.11, 4.13, 4.14
Types.-Holotype MMNS 7099. Paratype MMNS 7097 from the Clayton Formation (McBryde Member), Resource Management Services Palmyra tract, Lowndes County, Alabama.

Diagnosis.-Test small. Apical disc rounded, distinct pits along genital-genital, genital-ocular, and suranal plate suture, plates smooth and lacking granules, oculars excert. Ambulacra bigeminate throughout. Interambulacra with five or six plates in a column. Peristome $\sim 40 \%$ of test diameter, with small notches.

Description.-Test small, slightly rounded above and flattened aborally. Apical disc rounded, $\sim 70 \%$ of test diameter, low in profile. Two or three distinct pits along genital-genital, genitalocular, and suranal plate sutures. All apical disc plates smooth and lacking granules. Periproct subtrigonal, at junction of genital plates 1 and 5 and suranal plate, separated from ocular plate I. All oculars excert. Ambulacra strictly bigeminate with hardly any pore crowding adorally. Columns of primary ambulacral tubercles separated by less than the diameter of one tubercle; no discernible secondary tubercles perradially. Interambulacra with five or six plates in a column. Interradial zone narrow with few granules outside the scrobicular ring. Peristome $\sim 40 \%$ of test diameter, with small notches.

Occurrence.-Clayton Formation (McBryde Member), Resource Management Services Palmyra tract, west of State Highway 263, entrance 2 miles north of Butler-Lowndes County line, Lowndes County, Alabama (UTM Zone 16, E 525,183 m, N 3,539,105 m, NAD83) (Types). Clayton Formation, Wade Pit, 0.5 mile west of US 27, 1.75 miles south of Stewart-Randolph County line, Randolph County, Georgia (UTM Zone 16, E 707,730m, N 3,531,375 m, NAD83).

Etymology.-Named for the old (now abandoned) settlement of Palmyra, Alabama.

Remarks.-The presence of smooth apical plates readily distinguishes this species from S. tumidula. Carter (1997) attributed three small test fragments collected from the Salt Mountain Limestone to Salenia? sp., but the figured plates lack the secondary tubercles observed on both $S$. palmyra n. sp. and $S$. tumidula. These fragments are indeterminate and no other species of Salenia are known from the Paleocene of the eastern United States.

Order Temnopleuroida Mortensen, 1942

Family Glyphocyphidae Duncan, 1889 Genus Echinopsis Agassiz, 1840

Echinopsis diatreta (Morton, 1833)

1833 Cidaris diatretum Morton, p. 294.

1834 Cidarites diatretum; Morton, p. 75, pl. 10, fig. 10.

1858 Pseudodiadema diatretum; Desor, p. 73.

1864 Pseudodiadema diatretum; Cotteau, p. 519.

1893 Pseudodiadema diatretum; Clark, p. 46, pl. 13, figs. 1a-f.

1907 Pseudodiadema diatretum; Weller, p. 285, pl. 9, figs. 1-6.

1911 Pseudodiadema diatretum; Lambert and Thiéry, p. 190.

1915 Pseudodiadema diatretum; Clark in Clark and Twitchell, p. 56, pl. 19, figs. 1a-f. 
1941 Pseudodiadema diatretum; Cooke, p. 8.

1959 Echinopsis diatreta; Cooke, p. 14, pl. 2, figs. 8-11.

2000 ?Echinopsis diatreta; Smith and Jeffery, p. 128.

Type.-ANSP 1471, reported lost, from the Vincentown Formation, Gloucester, Camden County, New Jersey.

Description.-Small, tumid. Apical disk pentagonal. Ambulacra quadrigeminate at ambitus, phymosomatoid compounding, otherwise trigeminate. Single large perforate, crenulate tubercle per interambulacral plate. Peristome weakly notched, about one third of total diameter, no phyllodes.

Additional material.- No material attributable to this species was located.

Occurrence.-Vincentown Formation, Gloucester, Camden County, New Jersey (exact locality unknown).

Remarks.-Description is based on the original published description. Even though a number of otherwise small, indeterminate regular urchins have been collected from Paleocene deposits in the eastern United States, they cannot be attributed to this species.

Genus Micropsidia Pomel, 1869

Micropsidia salis (Cooke, 1941)

Figures 5.1-5.3, 6

1941 Thylechinus (Gagaria) salis Cooke, p. 13, pl. 2, fig. 12-14.

1959 Gagaria salis; Cooke, p. 17, pl. 3, figs. 7-9.

1977 Gagaria sp. Toulmin, p. 178, pl. 9, fig. 8, 9.

1997 Gagaria? salis; Carter, p. 51.

2000 Micropsidia salis; Jagt, p. 245, pl. 9, figs. 12, 13, 15.

2000 Micropsidia salis; Smith and Jeffery, p. 126, text-fig. 51e-g.

Type.-USNM 166497, from the Salt Mountain Limestone, Salt Mountain, Clarke County, Alabama.

Description.-Small, subhemispherical. Apical disk small, hemicyclic, one ocular (I) insert. Ambulacra trigeminate, lower plate dominant (echinoid style), narrow, about half as wide as interambulacra at ambitus. Single, relatively small imperforate, crenulate tubercle per interambulacral plate, each with four to six secondary tubercles adapically; one primary tubercle per compound ambulacral plate.

Additional material.-MMNS 5304.1, MMNS 5304.2, and MMNS 5304.3, from the Clayton Formation (McBryde Member), Resource Management Services Palmyra tract, Lowndes County, Alabama.
Occurrence.-Salt Mountain Limestone, Salt Mountain, Clarke County, Alabama (UTM Zone 16, E 417,423 m, N 3,478,716 m, NAD83). Clayton Formation (McBryde Member), Resource Management Services Palmyra tract, west of State Highway 263, entrance 2 miles north of Butler-Lowndes County line, Lowndes County, Alabama (UTM Zone 16, E 525,183 m, N 3,539,105 m, NAD83).

Remarks.-Description is based on the original published description. Cooke $(1941,1959)$ reported ocular I to be insert, confirmed by observation here, as shown by the drawing in Figure 6 .

Order Phymosomatoida Mortensen, 1904

Family Phymosomatidae Pomel, 1883 Genus Gauthieria Lambert, 1888

Gauthieria speciosa (Clark, 1891)

Figure 5.4-5.7

1891 Cyphosoma speciosum Clark, p. 76.

1893 Coptosoma speciosum; Clark, p. 52, pl. 18, figs. 1a-h.

1907 Pseudodiadema speciosum; Weller, p. 286, pl. 9, figs 7-14.

1915 Coptosoma speciosum; Clark in Clark and Twitchell, p. 61, pl. 19, figs. 3a-h.

1935 Gauthieria? speciosa; Mortensen, p. 474.

1941 Microsoma speciosa; Cooke, p. 12, pl. 3, figs. 1-4.

1959 Gauthieria speciosa; Cooke, p. 23, pl. 5, figs. 1-7.

2000 Gauthieria speciosa; Smith and Jeffery, p. 95.

Type.-ANSP 1468, from the Vincentown Formation, Timber Creek, New Jersey.

Description.-Small, circular, relatively flat, very slight invagination of oral surface. Apical disk large, pronged posteriorly, details of apical disc unknown. Ambulacra about half as wide as interambulacra, pore pairs linear for most part, a little arcuate above the ambitus; quadrigeminate, phymosomatoid compounding, becoming trigeminate near apical disc. Peristome about a third of test diameter, circular, weakly notched. Primary tubercles imperforate, crenulate.

Additional material.-MMNS 4434, from the Clayton Formation, below Ft. Gaines Dam, Ft. Gaines, Clay County, Georgia.

Occurrence.-Vincentown Formation, Timber Creek, Gloucester County, New Jersey (exact locality unknown). Rancocas Creek, Vincentown, Burlington County, New Jersey (UTM Zone 18, E 520,995 m, N 4,421,446 m, NAD83); Clayton Formation, banks of Chattahoochee River below Ft. Gaines Dam, Ft. Gaines, Clay County, Georgia (UTM Zone 16, E 684,113 m, N 3,500,292 m, NAD83).

Remarks.-Description is based on the original published description. The Georgia specimen differs from the New Jersey

Figure 5. Micropsidia salis (Cooke, 1941) from the Clayton Formation, Palmyra tract, Lowndes County, AL: (1) MMNS 5304.3, aboral; (2) MMNS 5304.3, detail of ambulacrum; (3) MMNS 5304.2, aboral. Gauthieria speciosa (Clark, 1891) from the Clayton Formation, Ft. Gaines, Clay County, GA; (4) MMNS 4434, aboral; (5) MMNS 4434, oral; (6) MMNS 4434, profile; (7) MMNS 4434, detail of ambulacrum. Arbaciella? sp. from the Clayton Formation, Starkville, Oktibbeha County, MS: (8) MMNS 7814, aboral; (9) MMNS 7814, oral; (10) MMNS 7814, detail of tags on peristome margin Scale bars are (1, 3,8,9) 5 mm; $(\mathbf{2}, \mathbf{7}) 2 \mathrm{~mm} ;(\mathbf{4 - 6}) 10 \mathrm{~mm} ;(\mathbf{1 0}) 1 \mathrm{~mm}$. 


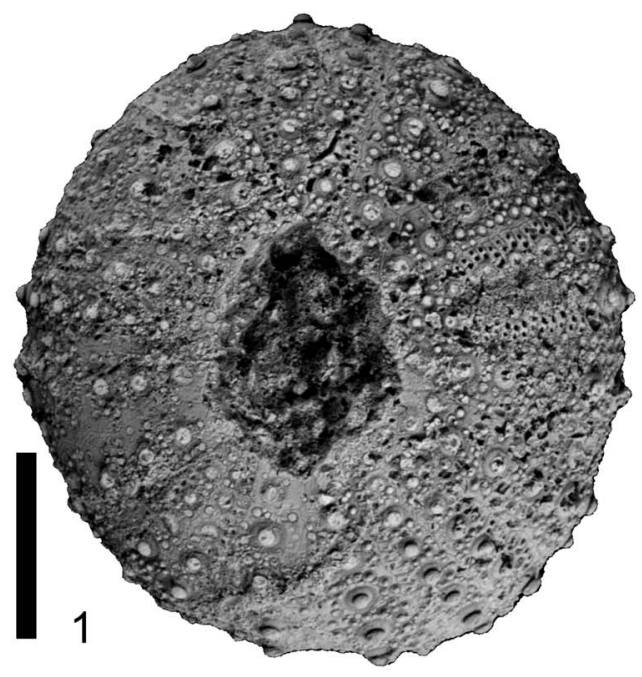

2
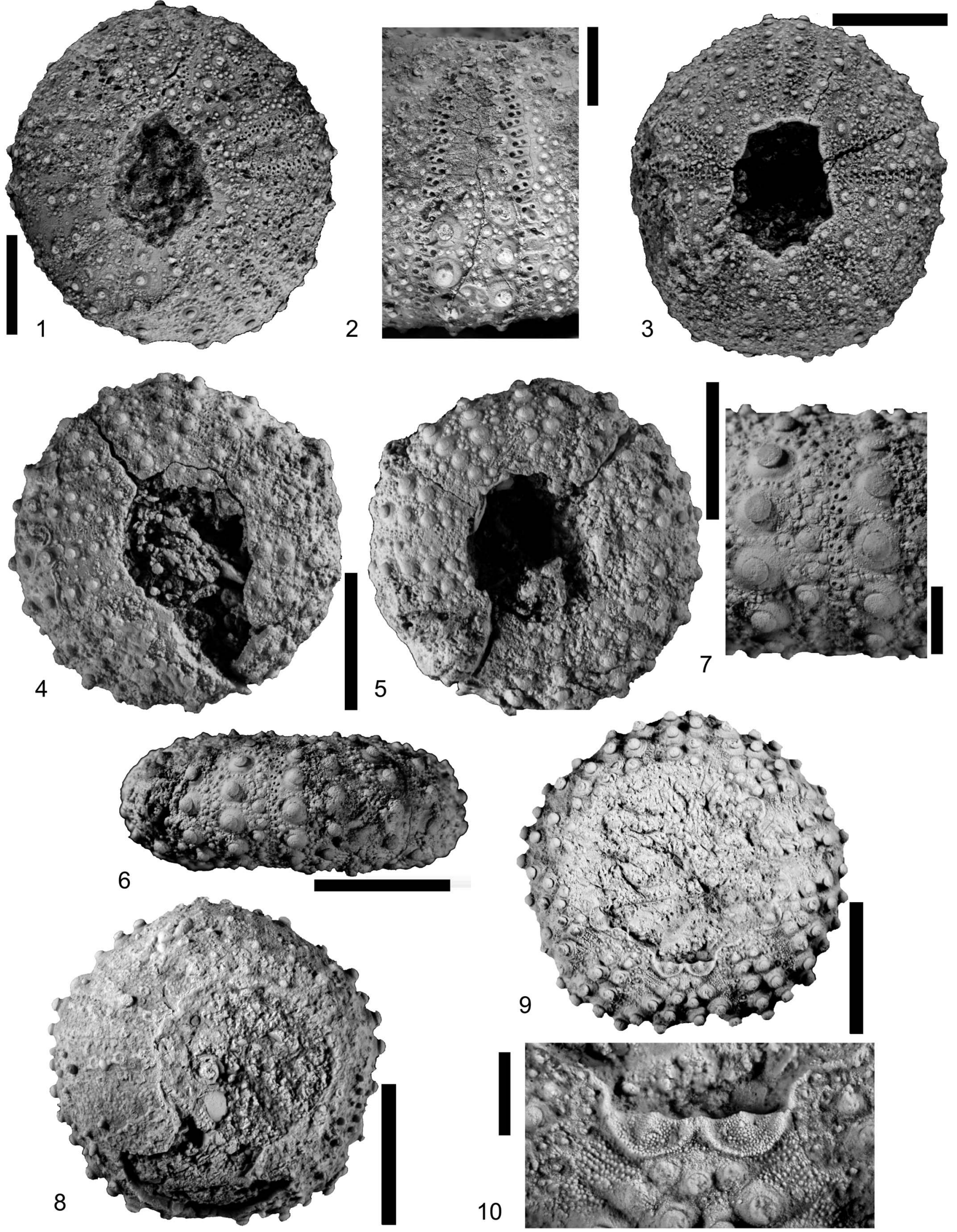


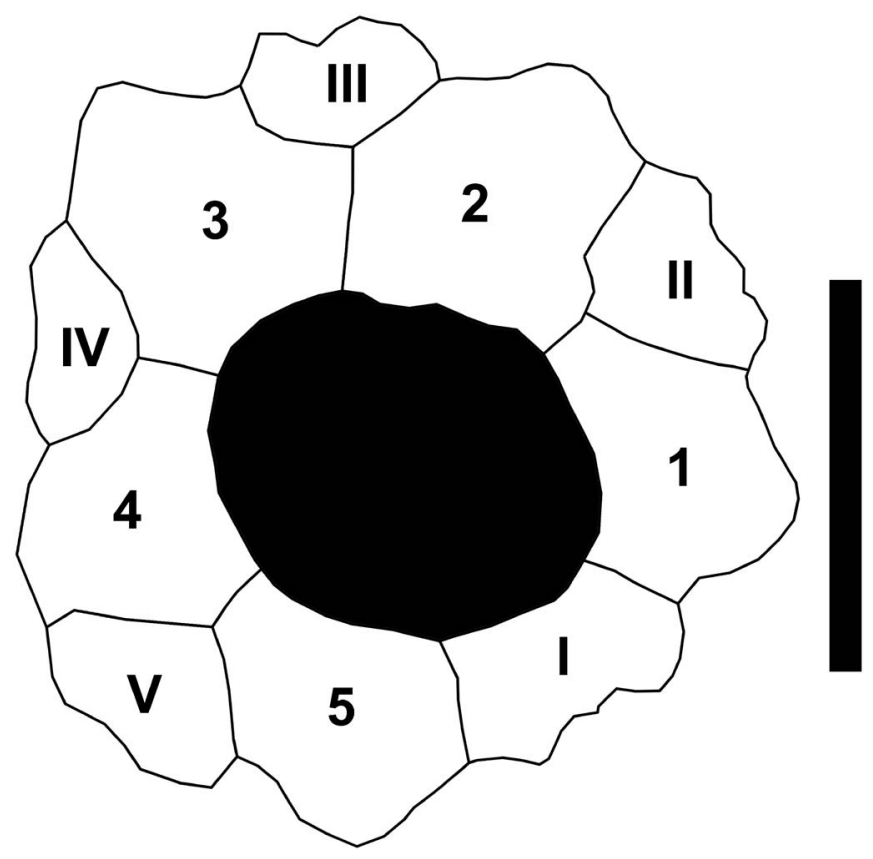

Figure 6. Micropsidia salis (Cooke, 1941), MMNS 5304.1 from the Clayton Formation, Palmyra tract, Lowndes County, AL. Detail of apical disc showing insert ocular I, with annotation following the plate-naming convention of Lovén (1874). Scale bar $2 \mathrm{~mm}$.

material in the size of secondary tubercles, which are larger in the Vincentown specimens.

Order Arbacioida Gregory, 1900

Family Arbaciidae Gray, 1855

Genus Arbaciella Mortensen, 1910

Arbaciella? sp.

Figure 5.8-5.10

Material.-MMNS 7814, from the Clayton Formation, Starkville, Oktibbeha County, Mississippi.

Diagnosis.-Imperforate, non-crenulate tubercles below the ambitus, peg-like pustules above, with vertical epistromal ridges linking larger pustules. Slight buccal notches, well-developed tags, single perradial sphaeridial pit.

Description.-Small. Primary tubercles imperforate and noncrenulate, one to each ambulacral plate, two to each interambulacral plate, restricted to area below ambitus; smaller, peg-like pustules aborally, in oblique linear sets, usually one per ambulacral plate, three per interambulacral plate, vertical epistromal ridges link larger pustules. Ambulacra trigeminate, apparently throughout (but preservation obscures some of the ambulacra), pores equal sized, arbacioid compounding.
Peristome large, $\sim 60 \%$ of diameter, slight buccal notches, welldeveloped tags, single perradial sphaeridial pit.

Occurrence.-Clayton Formation, 0.25 mile east of State Highway 25 between MLK Dr. and Pollard Rd., west side of Starkville, Oktibbeha County, Mississippi (UTM Zone 16, E $328,035 \mathrm{~m}, \mathrm{~N} 3,702,780 \mathrm{~m}, \mathrm{NAD} 83)$.

Remarks.-A single specimen with broken and incomplete aboral surface was found just above the paraconformity between the Upper Cretaceous Prairie Bluff Chalk and the Paleocene Clayton Formation. The incompleteness of the specimen, in particular the complete lack of genital plates, precludes a complete description of the species and definitive generic assignment. It is left in open nomenclature pending discovery of additional material. Because of the overlap of the interambulacral tags, a primibasal plate is not discernible, nor is a single primary tubercle, evidence that this is not a species of the closely related genus Podocidaris. Additionally, there is uncertainty as to the validity of the genus Arbaciella itself (Kroh et al., 2012), further justifying the indefinite generic assignment of this species.

Order Cassiduloida Agassiz and Desor, 1847

Family Pygaulidae Lambert, 1905

Genus Plagiochasma Pomel, 1883

Plagiochasma cruciferum (Morton, 1830a)

Figures 7.1, 7.2, 8.1-8.5

1830a Ananchytes cruciferus Morton, p. 245, pl. 3, fig. 8.

1830b Ananchytes cruciferus; Morton, p. 201.

1833 Nucleolites crucifer; Morton, p. 294.

1834 Nucleolites crucifer; Morton, p. 75, pl. 3, fig. 15.

$1840 \quad$ Nucleolites crucifer; Agassiz, p. 4.

1847 Nuculites cruciferus; Agassiz and Desor, p. 155.

1850 Nucleolites cruciferus; d'Orbigny, p. 271.

1850 Pygorhynchus crucifer; Ravenel, p. 160.

1854 Echinobrissus crucifer; d'Orbigny, p. 25.

1853- Trematopygus crucifer; d'Orbigny, p. 387, pl. 953,

1856 figs. 10-11; pl. 963, figs. 1-5.

1858 Nucleolites (Trematopygus) crucifer; Desor, p. 262.

1891 Trematopygus crucifer; Clark, p. 76.

1893 Trematopygus crucifer; Clark, p. 63, pl. 27, figs. 1a-i.

1907 Trematopygus crucifer; Weller, p. 289, pl. 11, figs. 1-9.

1915 Trematopygus cruciferus; Clark in Clark and Twitchell, p. 71, pl. 28, figs. 3a-c; pl. 29, figs. 1a-f.

1942 Trematopygus crucifer; Cooke, p. 10.

1959 Rhopostoma cruciferum; Cooke, p. 26, pl. 7, figs. 1-4.

1977 Rhopostoma cruciferum; Toulmin, p. 179, pl. 9, figs. 10-13.

1982 Rhopostoma cruciferum; Rose, p. 149.

2000 Plagiochasma cruciferum; Jagt, p. 252, pl. 17, figs. 4-6.

Figure 7. Plagiochasma cruciferum (Morton, 1830) from the Clayton Formation, Cedar Creek, Butler County, AL: (1) MMNS 7173.1, aboral; (2) MMNS 7173.1, oral. Gitolampas georgiensis (Twitchell, 1915) from the Clayton Formation, Palmyra tract, Lowndes County, AL: (3) MMNS 5299.1, aboral; (4) MMNS 5299.1, oral; (5) MMNS 5299.2, detail of apical disc; (6) MMNS 5299.1, posterior. Pseudholaster cinctus (Morton, 1830) from the Vincentown Formation, Big Brook, Marlboro, Monmouth County, New Jersey: (7) USNM 540912, aboral; (8) USNM 540912, oral. Echinocorys ovalis (Clark, 1893) from the Vincentown Formation, Vincentown, Burlington County, NJ: (9) USNM 636366, lectotype, aboral; (10) USNM 636366, lectotype, oral. Scale bars are (1, 2, 6) 10 mm; (5) $2 \mathrm{~mm}$; (3, 4, 7-10) $20 \mathrm{~mm}$. 

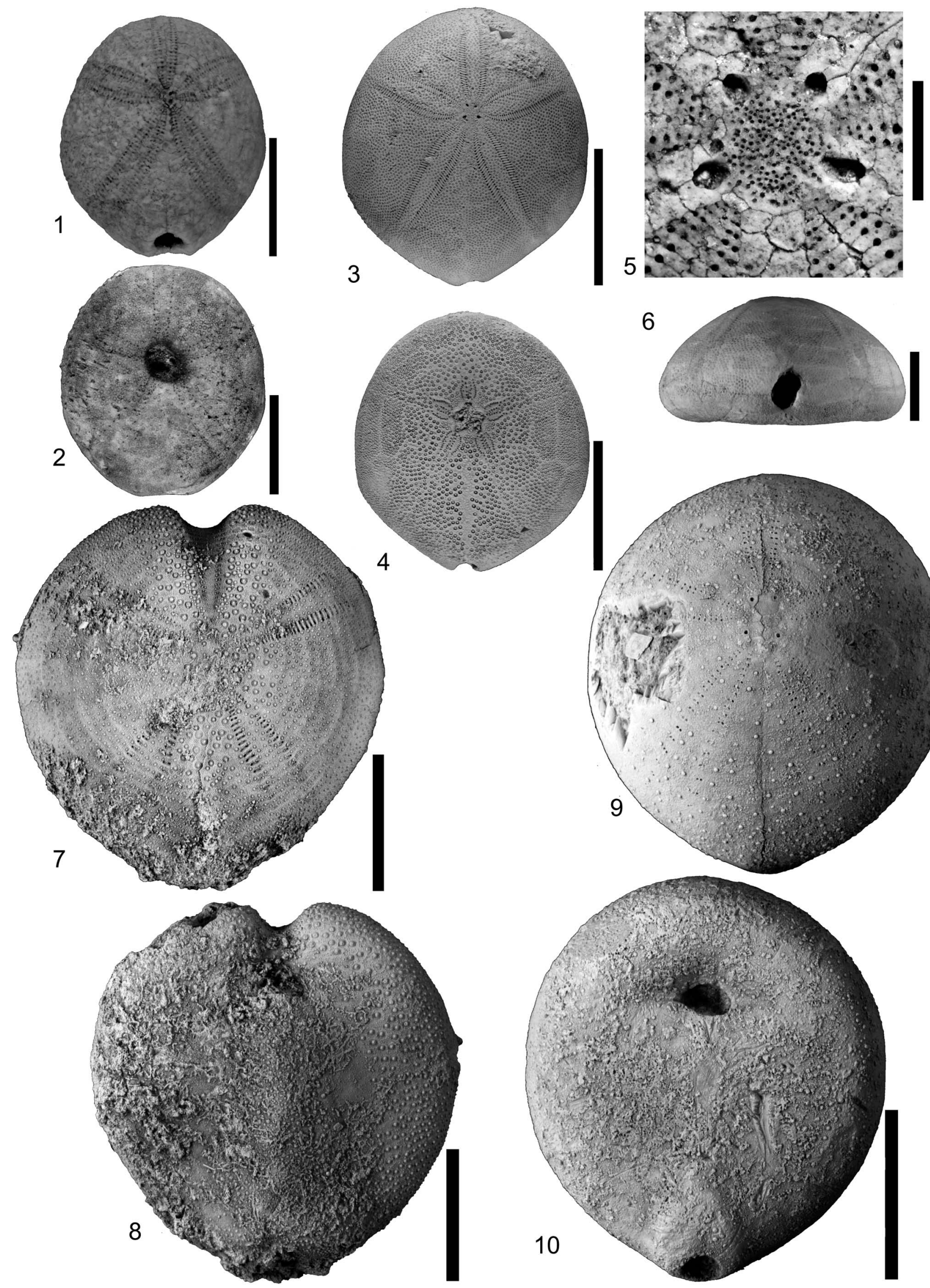
2000 Plagiochasma cruciferum; Smith and Jeffery, p. 163, text-fig. 66D-H.

2001 Plagiochasma cruciferum; Kroh, p. 392, figs. 12-14, pl. 3, figs. 4-8.

Type.-Holotype ANSP 1464, from the Vincentown Formation, Timber Creek, New Jersey.

Description.-Small, outline oval to elongate, tall, rounded profile with inflated oral surface. Apical disc semi-ethmolytic, slightly eccentric anteriorly, four genital plates, each penetrated by large pore (Fig. 8.4, 8.5). Madreporite well developed, expanding to separate posterior genital plates. Ocular plates distinct, posterior pair in contact. Ambulacra narrow, aborally subpetaloid, anterior pair diverges at $140^{\circ}$, posterior at $60^{\circ}$; pores round, nearly equal size, becoming unequal and strongly oblique below the margin, pore pairs weakly conjugate. Subpetaloid ambulacral plates simple (Fig. 8.1), but becoming occluded near the peristome in the pyrinoid fashion (Fig. 8.2, 8.3). Periproct large, longitudinal, often distinctly pointed adapically, marginal in larger specimens, strongly supramarginal in smaller, more juvenile specimens, with slight indentation of posterior margin, but without a clearly defined groove. Peristome oblique, central to slightly anterior, sunken, proximal plates rotated nearly vertical to oral plane, no bourrelets, greatly reduced phyllode, no buccal pores, no sphaeridial pits, pore pairs crowded into offset triads. Single narrow basicoronal plates, deeply inset and generally only visible internally, abut peristome in all interambulacral columns. No evidence of lantern supports, either auricles or apophyses, although no juveniles were examined internally. Tubercles small, evenly distributed over aboral and oral surfaces, perforate, sunken.

Additional material.-MMNS 4889, Clayton Formation, Randolph County, Georgia; MMNS 5300, MMNS 7173, MMNS 8245, and MMNS 8246, from the Clayton Formation, Butler and Lowndes Counties, Alabama.

Occurrence.-Vincentown Formation, Timber Creek, Gloucester Co., New Jersey (exact locality unknown). Clayton Formation (McBryde Member), Resource Management Services Palmyra
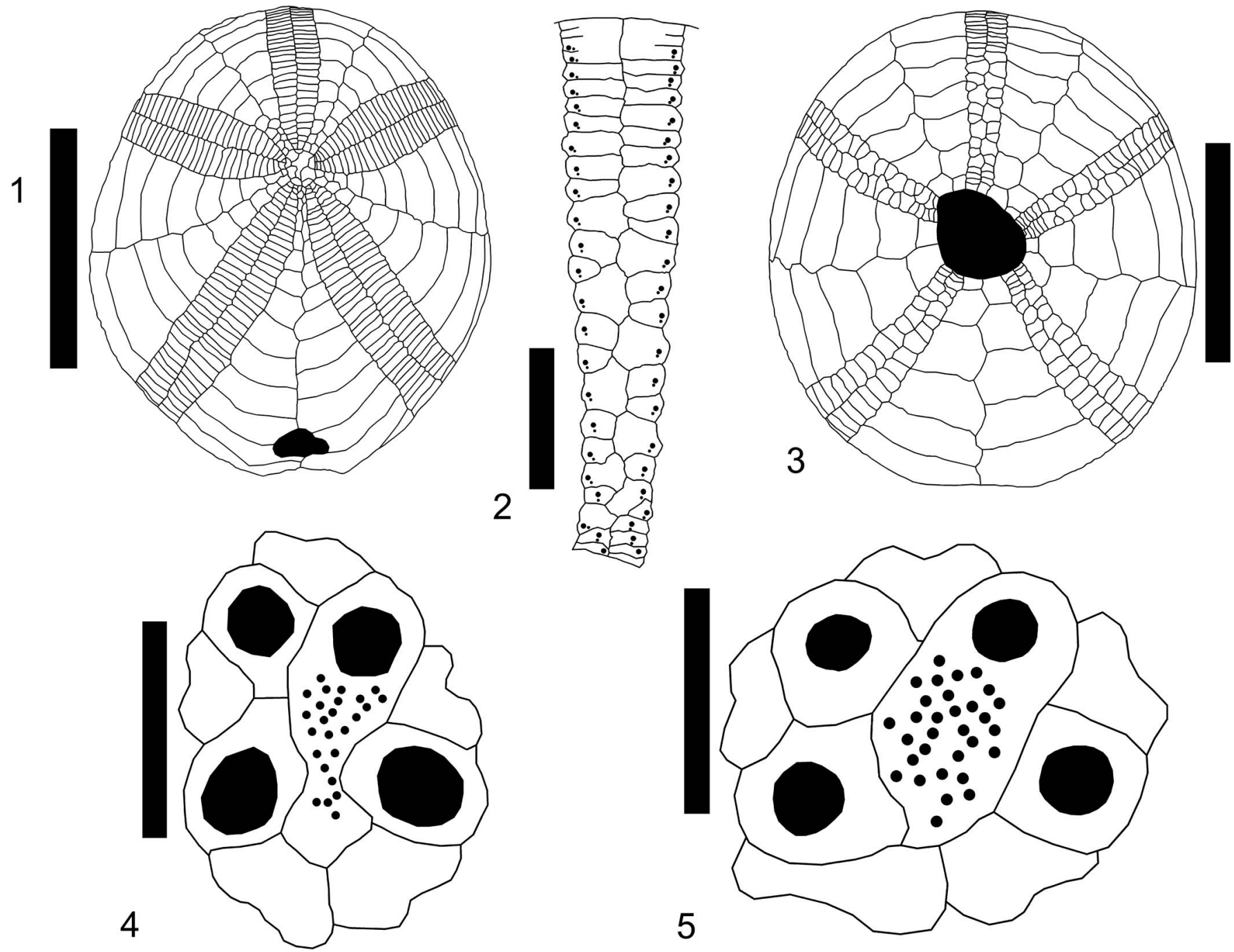

Figure 8. Plagiochasma cruciferum (Morton, 1830) from the Clayton Formation, Palmyra tract, Lowndes County, AL: (1) MMNS 7173.1, aboral plate pattern; (2) MMNS 7173.1, detail of ambulacrum III, oral, from anterior edge of peristome to anterior margin; (3) MMNS 5300.4, oral plate pattern; (4) MMNS 8245, detail of semi-ethmolytic apical disc; (5) MMNS 8246, detail of semi-ethmolytic apical disc. Scale bars are (1, 3) $10 \mathrm{~mm} ;(\mathbf{2}) 2 \mathrm{~mm} ;(\mathbf{4}, \mathbf{5}) 1 \mathrm{~mm}$. 
tract, west of State Highway 263, entrance 2 miles north of ButlerLowndes County line, Lowndes County, Alabama (UTM Zone 16, E 525,183 m, N 3,539,105 m, NAD83). Clayton Formation, Wade Pit, 0.5 mile west of US 27, 1.75 miles south of Stewart-Randolph County line, Randolph County, Georgia (UTM Zone 16, E 707,730 m, N 3,531,375 m, NAD83). Other localities in New Jersey (Vincentown Fm.) and Alabama, Arkansas, and Georgia (Clayton Fm.) listed by Cooke (1959) and Toulmin (1977).

Remarks.-The description is expanded on the basis of new material from Alabama. Cooke (1959) erected the genus Rhopostoma based on the lack of well-defined petals and the poor development of the phyllodes to distinguish this genus, which he considered to be an echinoneoid, from the cassiduloid genus Trematopygus $(=$ Plagiochasma $)$. Even though d'Orbigny (1853-1856) stated the publication date of his new genus Trematopygus as 1855, Sherwood (1899) reported that the actual publication date was 1858. Melville (1952) pointed out that the name Trematopygus d'Orbigny was preoccupied by Trematopygus Holmgren (an olive fly). However, although the stated publication date of Holmgren's genus is 1855 , the actual publication date seems to be 1858 (Holmgren, 1858). Regardless, the currently accepted date is 1855 (Hinz, 1985), and Trematopygus d'Orbigny is considered invalid. Plagiochasma, considered a junior synonym of Trematopygus by Lambert and Thiéry (1921), was therefore reinstated by Melville (1952).

Cooke (1959) stated that the posterior ocular plates were not in contact in Rhopostoma ( = Plagiochasma) cruciferum, but this is clearly not the case (Fig. 8.4, 8.5).

Smith and Kroh (2011) figured a specimen of Plagiochasma cruciferum from the NHM collection (NHM EE4686) reportedly from the Merchantille Formation, Chesapeake and Delaware Canal, St. Georges County, Delaware. The collections made from this canal are from Cretaceous units and the Merchantille Formation is considered to be Campanian in age, not Paleocene (Lauginiger, 1988). No other specimens are known from this locality.

Family uncertain Genus Gitolampas Gauthier, 1889

Gitolampas georgiensis (Twitchell, 1915) Figure 7.3-7.6

1915 Echinanthus georgiensis Twitchell, in Clark and Twitchell, p. 139, pl. 65, figs. 1a-d.

1942 Echanthus georgiensis; Cooke, p. 37, pl. 8, figs. 1-3.

1959 Echanthus georgiensis; Cooke, p. 62, pl. 26, figs. 13-16. 1962 Gitolampas georgiensis; Kier, p. 211, text-fig. 172, pl. 40, figs. 3-15.

1977 Gitolampas georgiensis; Toulmin, p. 178, pl. 9, figs. 14-16. 2000 Gitolampas georgiensis; Smith and Jeffery, p. 227.

Type.-USNM 165683b, from the Clayton Formation, 5 miles south of Ellaville, Schley County, Georgia.

Description.-Medium size, outline subpentagonal, often somewhat protruding posteriorly, low to slightly inflated, lower surface concave around peristome, margin rounded. Apical disc monobasal, four genital pores opening into the proximal ends of the paired interambulacra; ocular plates small but distinct. Petals long and narrow, anterior pair diverge at $140^{\circ}$, posterior pair diverge at $60^{\circ}$. Petals extend nearly to margin, open distally; pores circular to elliptical, conjugate, oblique in midsection; interporiferous zones up to twice as wide as poriferous zones; pores single beyond petals, one pore per ambulacral plate orally, restricted to adradiad sutures except in floscelle. Peristome anterior, pentagonal, nearly equant; phyllodes well developed, one, sometimes two sphaeridial pits, bourrelets slightly inflated. Periproct marginal, enclosed between $5^{\text {th }}$ pair of post-basicoronal plates below the ambitus and the $6^{\text {th }}$ pair above (obscured by plate fractures in Fig. 7.6), vertical, taller than wide, indents posterior margin. Aboral and marginal surface covered in small, sunken tubercles interspersed with fine granules; tubercles larger on oral surface, increasing in size and decreasing in density towards peristome, but denser and smaller within area of the floscelle, fading into granules on the bourrelets; narrow, naked sternal area.

Additional material.-MMNS 5299, from the Clayton Formation, Resource Management Services Palmyra tract, Lowndes County, Alabama.

Occurrence.-Clayton Formation, Dr. A.J. Parkes farm, 5 miles south of Ellaville, Schley County, Georgia (exact location unknown). Clayton Formation (McBryde Member), Resource Management Services Palmyra tract, west of State Highway 263, 2 miles north of Butler-Lowndes County line, Lowndes County, Alabama (UTM Zone 16, E 525,183 m, N 3,539,105 m, NAD83). Cedar Creek, either side of State Highway 263, 6 miles northwest of Greenville, Butler County, Alabama (UTM Zone 16, E $529,209 \mathrm{~m}, \mathrm{~N} 3,531,611 \mathrm{~m}$, NAD83). Other localities in Alabama listed by Cooke (1959) and Toulmin (1977).

Remarks.-The description is expanded based on new material from Alabama. Cooke (1959) placed ?Cassidulus (Galerolampas) fontis Cooke (1959) in synonymy with this species, but the type of $C$. fontis has better developed bourrelets and a transverse peristome (with no evidence of the crushing of the periproctal region described by Cooke). The type of $C$. fontis (USNM 498997) was recovered from well washings originating from an unknown depth and formation. It was included in a larger lot of fossils, the remainder of which are now unfortunately lost. Cooke (1959) described the type of G. georgiensis (USNM 165683b) as a siliceous pseudomorph. The specimen is actually recrystallized calcite, though eroded on the aboral surface. Many of the specimens from the vicinity of Luverne, Alabama (some collected from now abandoned shallow open pit iron mines) are internal molds composed of hematite. A few specimens are beautiful replacements of the original calcite test with hematite.

Gitolampas georgiensis is one of the most common echinoids found in the Clayton Formation in Alabama.

Order Holasteroida Durham and Melville, 1957 Family Holasteridae Pictet, 1857

Subfamily Pseudholasterinae Smith and Jeffery, 2000 Genus Pseudholaster Pomel, 1883

Pseudholaster cinctus (Morton, 1830a)

Figure 7.7, 7.8 
1830a Ananchytes cinctus Morton, p. 246, pl. 3, fig. 7. 1830a Ananchytes fimbriatus Morton, p. 245, pl. 3, fig. 9. 1830b Ananchytes cinctus; Morton, p. 200.

1830b Ananchytes fimbriatus; Morton, p. 200.

1834 Ananchytes cinctus; Morton, p. 78, pl. 3, fig. 19.

1834 Ananchytes fimbriatus; Morton, p. 78, pl. 3, fig. 20.

1840 Holaster cinctus; Agassiz, p. 1.

1847 Holaster fimbriatus; Agassiz and Desor, p. 141.

1851- Cardiaster cinctus; Bronn, p. 205.

1852

1853- Cardiaster cinctus; d'Orbigny, p. 147, pl. 905, fig. 4.

1856

1853- Cardiaster fimbriatus; d'Orbigny, p. 147, pl. 905, fig. 3.

1856

1858 Cardiaster cinctus; Desor, p. 346.

1891 Holaster cinctus; Clark, p. 77.

1893 Cardiaster cinctus; Clark, p. 75, pl. 37, figs. 1a-h.

1907 Cardiaster cinctus; Weller, p. 296, pl. 16, figs. 1-8.

1915 Cardiaster cinctus; Clark in Clark and Twitchell, p. 83, pl. 36, figs. 2a-h.

1942 Holaster cinctus; Cooke, p. 52.

1959 Holaster cinctus; Cooke, p. 65, pl. 27, figs. 1-5.

Type.-Holotype ANSP 1485, from the Vincentown Formation, Timber Creek, New Jersey. Holotype of Ananchytes fimbriatus ANSP 38170 (ex “258”, ex “1485”).

Description.-Test cardiate, domal, notched anteriorly, oral surface nearly flat, with slight posterior keel. Apical disc slightly anterior of center, elongate, paired plates juxtaposed, four genital pores. Anterior ambulacrum depressed, pores small, pore pairs slightly oblique, ornamented with two small tubercles or beads. Paired ambulacra flush, subpetaloid, open distally, anterior pair diverge at $140^{\circ}$, posterior pair diverge at $70^{\circ}$; pores equal, elongate, conjugate. Periproct elliptical, taller than wide. Peristome in anterior quarter of test, semicircular, transverse, lipped. Primary tubercles crenulate, sunken aborally, largest aborally in anterior paired interambulacra and proximal to apical disc, reduced in size towards margin; large but flush orally in paired interambulacra, constant size, with asymmetric areoles, posterior paired ambulacra naked orally, finer tuberculation covers plastron. Plastron protosternous, possibly with small extension of labrum in contact with second sternal plate. No fascioles.

Additional material.-USNM 29467, USNM 540912, Vincentown Formation, Burlington and Monmouth Counties, New Jersey.

Occurrence.-Vincentown Formation, Timber Creek, Gloucester County, New Jersey (exact locality unknown). Other localities in Rancocas Creek, Vincentown, Burlington County, and Big Brook, Marlboro, Monmouth County, New Jersey listed by (Cooke, 1959).

Remarks.-Description is based on the original description. There is little to add to Cooke's (1959) description. The deep anterior sulcus and protosternous plating of $P$. cinctus are basis for its placement in Pseudholaster rather than Holaster.
Morton's (1830a) species Ananchytes cinctus and A. fimbriatus were synonymized by Clark (1891) as Holaster cinctus. Smith and Jeffery (2000) suggested that $P$. cinctus is synonymous with $P$. faxensis (Hennig, 1898), but $P$. cinctus differs by a deeper and more pronounced anterior sulcus and a smaller peristome set farther back from the anterior margin.

\section{Subfamily Echinocorythinae Wright, 1856 Genus Echinocorys Leske, 1778}

Echinocorys ovalis (Clark, 1893)

Figure $7.9,7.10$

1893 Ananchytes ovalis Clark, p. 74, pl. 36, figs. 1a-h.

1907 Ananchytes ovalis; Weller, p. 295, pl. 13, figs. 1-8.

1915 Ananchytes ovalis; Clark in Clark and Twitchell, p. 81, pl. 35, figs. 1a-h.

1924 Echinocorys ovalis; Lambert and Thiéry, p. 418.

1942 Echinocorys ovalis; Cooke, p. 39.

1959 Echinocorys ovalis; Cooke, p. 66, pl. 27, figs. 6-9.

Type.-There were two specimens with the identification USNM 559479 in the Smithsonian collection. Clark in Clark and Twitchell (1915), figured as the type the specimen with damage to the aboral portion of interambulacrum 4 . This is the same specimen figured by Cooke (1959) as a cotype, and is here designated the lectotype, with a new catalog number USNM 636366. The other specimen, with damage to the posterior of the test, has the new catalog number USNM 636367. Both specimens are from the Vincentown Formation, Vincentown, New Jersey.

Description.-Outline ovate, profile domal with nearly flat oral surface, rounded margin, protruding somewhat around the submarginal periproct. Apical disc elongate, four gonopores, paired genital plates in contact, anterior pair separated from posterior by ocular plates; genital 2 (with madreporite) largest, genital 3 smallest plate. Ambulacra subpetaloid, pores elongate, pairs transverse near apical disc, becoming progressively more oblique towards margin, anterior pair diverge at $150^{\circ}$, posterior pair diverge at $60^{\circ}$. Peristome transverse, oval, inclined, in the anterior third of the test. Plastron meridosternous. Primary tubercles small, sparsely scattered, denser aborally towards posterior margin; denser on oral surface except posterior paired ambulacra naked. No fascioles.

Additional material.-UF 68910, from the Clayton Formation, Wilcox County, Alabama.

Occurrence.-Vincentown Formation, Vincentown, Burlington County, New Jersey (exact locality unknown). Clayton Formation (McBryde Member), creek west of Alabama River, off State Highway 10 east of Kimbrough, Wilcox County, Alabama (UTM Zone 16, E 460,334 m, N 3,536,159 m, NAD83).

Remarks.-Description is based on the original description. The UF specimen from Alabama is somewhat crushed and missing the apical area but in other respects is indistinguishable from material from the Vincentown Formation of New Jersey. 
Smith and Jeffery (2000) treated E. ovalis as a junior synonym of E. scutata Leske, 1778, which is not accepted here.

Order Spatangoida Agassiz, 1840

Family Hemiasteridae Clark, 1917

Genus Hemiaster Desor in Agassiz and Desor, 1847

Hemiaster parastatus (Morton, 1833)

Figure 9.1

1833 Spatangus parastatus Morton, p. 294.

1834 Spatangus parastatus; Morton, p. 77, pl. 3, fig. 21.

1847 Hemiaster parastatus; Agassiz and Desor, p. 141.

1853- Hemiaster parastatus; d'Orbigny, p. 265, pl. 894, 1856 figs. 3,4 .

1858 Hemiaster parastatus; Desor, p. 373.

1859 Hemiaster parastatus; Gabb, p. 19.

1893 Hemiaster parastatus; Clark, p. 83, pl. 44, figs. 1a-m.

1907 Hemiaster parastatus; Weller, p. 298, pl. 15, figs. 1-3.

1915 Hemiaster parastatus; Clark in Clark and Twitchell, p. 92 , pl. 48 , figs. 1a-n.

1924 Hemiaster (Leymeriaster) parastatus; Lambert and Thiéry, p. 501.

1942 Hemiaster parastatus; Cooke, p. 43.

1959 Hemiaster parastatus; Cooke, p. 67, pl. 28, figs. 15-20.

2000 Hemiaster parastatus; Smith and Jeffery, p. 326.

Type.-Holotype ANSP 1487, from the Vincentown Formation, Timber Creek, New Jersey.

Description.-Medium, ovate, rounded, widest and slightly emarginate anteriorly, apex near posterior end. Apical disc posterior of center, ethmophract, four genital pores, lateral pairs closer. Anterior ambulacrum shallowly depressed, uniserial series of paired zygopores to just above peripetalous fasciole, outer pores larger than inner, separated by large tubercle or bead, interporiferous surface covered with fine granulation. Anterior petals about three times length of posterior, broadly flaring near distal tips, nearly closed, slight anterior flexure, diverge at $90^{\circ}$; posterior petals short and broad, also diverge at $90^{\circ}$. All petals shallowly depressed, pores elongate, nearly equal, conjugate, interporiferous zones slightly wider than poriferous. Periproct oval, vertical. Peristome is anterior third, reniform, distinctly lipped. Complete peripetalous fasciole, no lateral fasciole. Ambulacral plates are slightly reduced where crossed by the fasciole, but not pinched to the degree characteristic of Holanthus. Primary tubercles small aborally, larger and less dense orally; posterior paired ambulacra naked. Labrum short, contacting sternal plates.

Additional material.-USNM 29472, from the Vincentown Formation, Burlington County, New Jersey.

Occurrence.-Vincentown Formation, Timber Creek, Gloucester County, New Jersey (exact locality unknown). Rancocas Creek, Vincentown, Burlington County, New Jersey (UTM Zone 18, E 520,995 m, N 4,421,446 m, NAD83).

Remarks.-Description is based on the original description. Hemiaster parastatus is readily distinguished from $\mathrm{H}$. stella, a sympatric hemiasterid in the Vincentown Formation, by its larger size and anterior emargination (which is not deep enough to merit the term notch).

Hemiaster stella (Morton, 1830a)

Figures 9.2, 9.4, 10

1830a Spatangus stella Morton, p. 245, pl. 3, fig. 11.

1830b Spatangus stella; Morton, p. 200.

1834 Spatangus stella; Morton, p. 78, pl. 3, fig. 18.

1847 Hemiaster stella; Agassiz and Desor, p. 141.

1853- Hemiaster stella; d'Orbigny, p. 245.

1856

1858 Hemiaster stella; Desor, p. 373.

1891 Hemiaster incrassatus; Clark, p. 77.

1893 Hemiaster stella; Clark, p. 84, pl. 46, figs. 1a-d.

1907 Hemiaster stella; Weller, p. 300, pl. 16, figs. 1-4.

1915 Hemiaster stella; Clark in Clark and Twitchell, p. 93, pl. 48, figs. 2a-d.

1924 Hemiaster (Integraster) stella; Lambert and Thiéry, p. 504.

1942 Hemiaster stella; Cooke, p. 44.

1959 Hemiaster stella; Cooke, p. 67, pl. 28, figs. 10-14.

2000 ?Hemiaster stella; Smith and Jeffery, p. 323, text-fig. 134a, b, f.

2001 ?Hemiaster stella; Kroh, p. 410, figs. 25, 26, pl. 12, figs. 1-8.

Type.- Holotype ANSP 1491, from the Vincentown Formation, Timber Creek, New Jersey.

Description.-Small, ovate to nearly circular, apex near posterior end, sloping anteriorly, posterior truncated, no anterior emargination. Apical disc posterior of center, ethmophract, four genital pores, all evenly spaced. Anterior ambulacrum very shallowly depressed, narrower than petals, paired zygopores above peripetalous fasciole, pore nearly equal size, separated by wall-like bead. Petals broad and very shallowly depressed, anterior petals more than twice length of posterior, straight, anterior pair diverge at $120^{\circ}$, posterior pair diverge at $90^{\circ}$, pores elongate, nearly equal size, interporiferous zone narrower than poriferous. Periproct small, barely visible from above. Peristome in anterior third of test, semicircular, elongate, lipped. Peripetalous fasciole complete, somewhat irregular, unindented. Labrum long, expanding posteriorly, contacts asymmetric, obliquely sutured sternal plates (Fig. 10). Primary tubercles small aborally, larger and less dense orally, posterior ambulacra naked orally.

Additional material.-MMNS 5095, from the Clayton Formation, Furman, Wilcox County, Alabama.

Occurrence.-Vincentown Formation, Timber Creek, Gloucester County, New Jersey (exact locality unknown). Timber Creek, Camden County and Rancocas Creek (exact locality unknown), Vincentown, Burlington County, New Jersey (UTM Zone 18, E 520,995 m, N 4,421,446m, NAD83). Clayton Formation (McBryde Member), Resource Management Services Palmyra tract, west of State Highway 263, 2 miles north of Butler-Lowndes County line, Lowndes County, Alabama. County Rd 11 near 

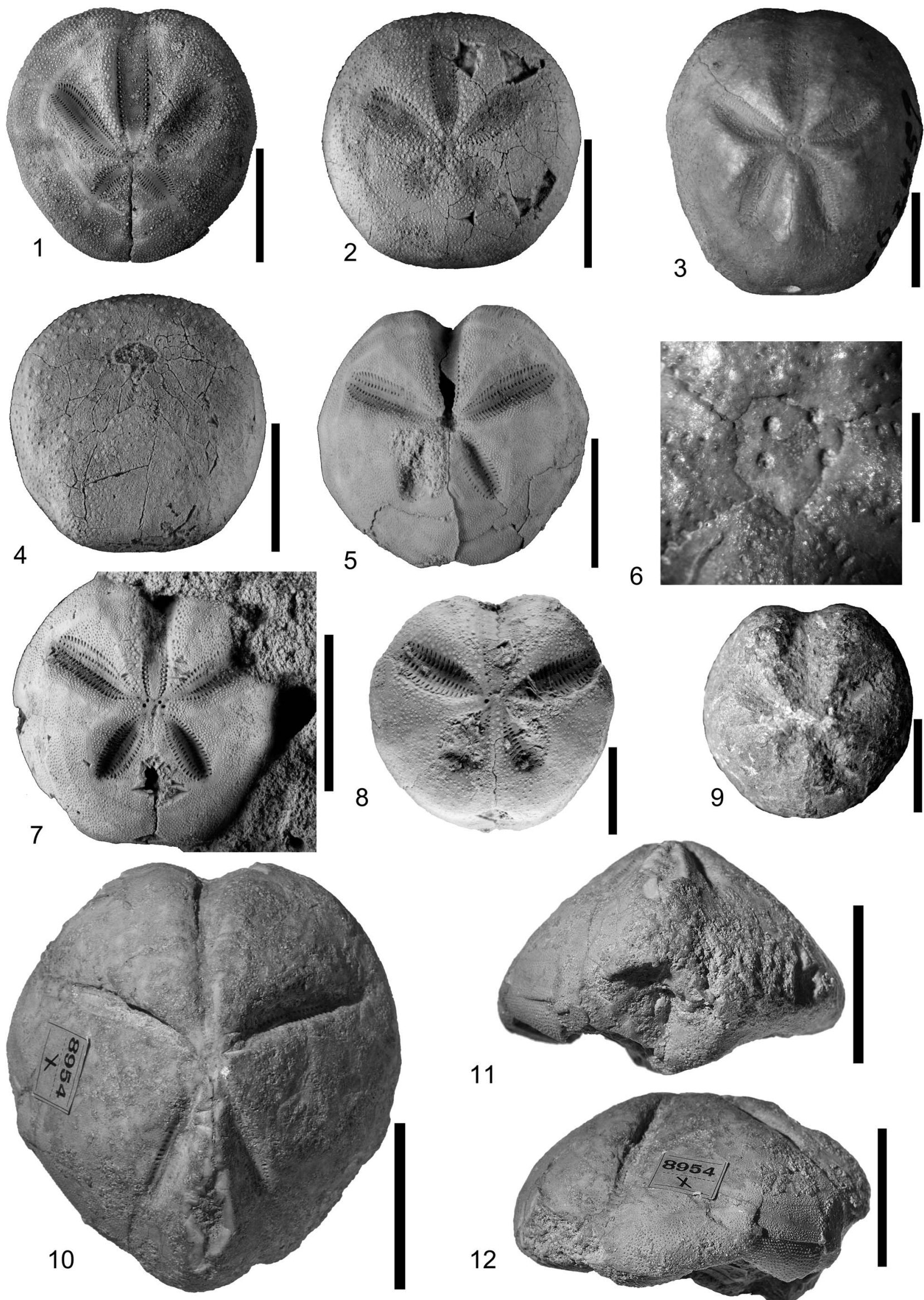

11
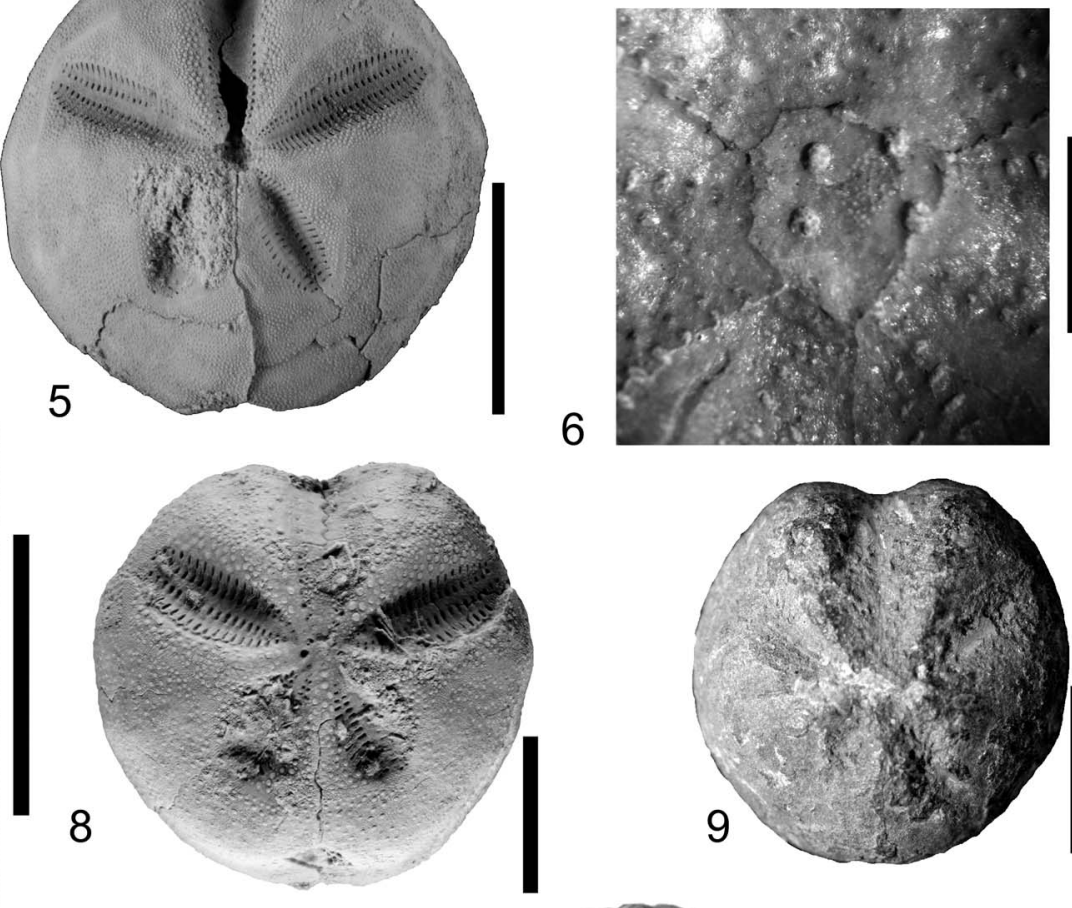

6

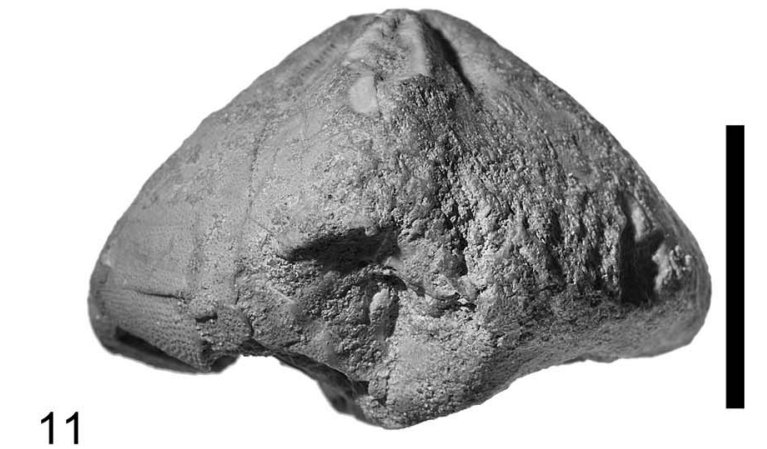

12

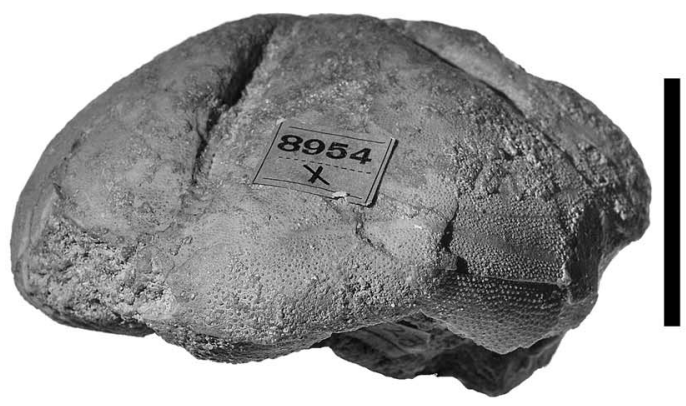




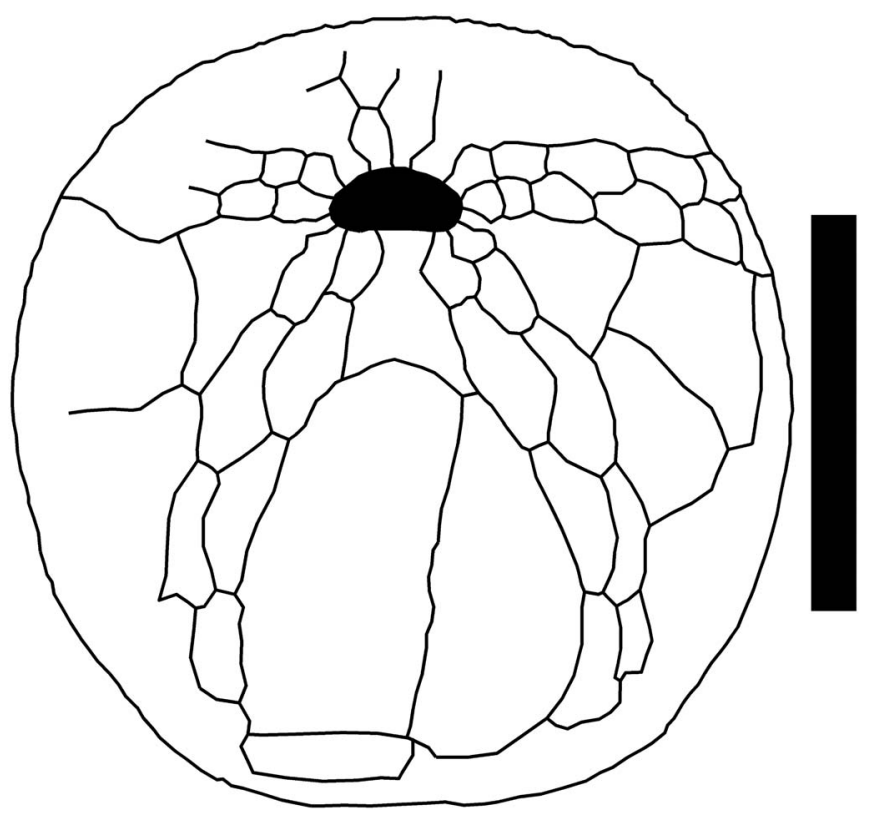

Figure 10. Hemiaster stella (Morton, 1830), MMNS 5095, oral plate pattern, from the McBryde Member, Clayton Formation, Furman, Wilcox County, AL. Scale bar $10 \mathrm{~mm}$.

Ridgeville, Butler County, Alabama (UTM Zone 16, E 525,183 m, N 3,539,105 m, NAD83); West of County Rd 59, 2.3 miles south of Furman, Wilcox County, Alabama (UTM Zone 16, E 502,537 m, N 3,538,048 m, NAD83).

Remarks.-The description is expanded based on new material from Alabama. This species is locally common in the Clayton Formation (Danian). Although superficially similar to small specimens of Linthia alabamensis, the two species are not found together in the Clayton Formation and apparently occupied different habitats. For this study, no comparison was made directly with European material attributed by Kroh (2001) or Smith and Jeffery (2000) to this species.

Family Micrasteridae Lambert, 1920

Genus Diplodetus Schlüter, 1900

Diplodetus moscovensis (Cooke, 1959) Figure 9.3, 9.6

1959 Hemiaster moscovensis Cooke, p. 68, pl. 28, figs. 5-9. 2000 Diplodetus? sp. indet. Smith and Jeffery, p. 310.

Type.-Holotype USNM 76285, probably from Prairie Bluff Chalk (Upper Cretaceous), Moscow Landing, Sumter County, Alabama.
Description.-Outline cuneate, slightly emarginate anteriorly, truncated posteriorly, apex behind apical disc, test gently sloping towards anterior; oral surface slightly convex, no keel. Apical disc nearly central, ethmophract, four genital pores. Anterior ambulacrum shallowly depressed, zygopore pairs equal size, separated by single tubercle or bead, becoming unipores just above peripetalous fasciole on anterior margin. Petals shallowly depressed, closed, nearly equal in length, anterior pair slightly flexed toward anterior, diverge at $130^{\circ}$, posterior pair more strongly flexed towards posterior and approaching final divergence at $40^{\circ}$; pores elongated, interior pores larger than exterior, interporiferous zone narrow, width equal to poriferous zones. Periproct small, taller than wide, inclined, visible from above. Peristome in anterior quarter of test, small, reniform to subpentagonal, lipped. Oral plating uncertain as a result of damage to sternal area. Peripetalous fasciole apparent only at the tips of the petals, probably complete, no lateral fasciole.

Occurrence.-Probably Prairie Bluff Chalk (Upper Cretaceous), Moscow Landing, Sumter County, Alabama (UTM Zone 16, E 402,209 m, N 3,587,818 m, NAD83).

Remarks.-Description is based on the original description. As noted by Smith and Jeffery (2000), there is no indication of a subanal fasciole on the type, but this portion of the test is badly worn and damaged. Reported from "Bed 3, Porters Creek Formation", but internal matrix is unlike any of the Porters Creek (late Danian) at Moscow Landing and appears to be identical with the Prairie Bluff Chalk (Maastrichtian) lithology seen in the lower part of the section below the exposed Cretaceous/Paleogene contact. This specimen is most likely from the Prairie Bluff Chalk, either by collection or as a reworked specimen. The station identifier (USGS 5658) on the original label suggests the specimen was collected by T.W. Vaughan prior to the description of the section by Stephenson (1915). The only stratigraphic notation on the label is "Bed 3". Smith et al. (1894) described the section at Moscow Landing, and here Bed 3 was described as a ledge containing the mollusk Gryphaea vomer, which was corrected by Smith (1910) to Ostrea pulaskensis ( = Pycnodonte pulaskensis), a guide fossil to the lower Clayton Formation (early Danian). Large numbers of $P$. pulaskensis are found just above the Cretaceous/ Paleogene contact at Moscow Landing.

The type of Hemiaster moscovensis is distinguishable from the type of Micraster ( = Diplodetus) americanus (Stephenson, 1941), from the Corsicana Marl (Maastrichtian), Bexar County, Texas, primarily by slight differences in the depth of the ambulacral depressions and the flexure of the petals. Otherwise, the similarities are so striking that even with lack of information regarding the presence or absence of a subanal fasciole this

Figure 9. Hemiaster parastatus (Morton, 1833) from the Vincentown Formation, Vincentown, Burlington County, NJ: (1) USNM 29472, aboral. Hemiaster stella (Morton, 1830) from the McBryde Member, Clayton Formation, Furman, Wilcox County, AL: (2) MMNS 5095, aboral; (4) MMNS 5095, oral. Diplodetus moscovensis (Cooke, 1959) from the Prairie Bluff Formation (?), Moscow Landing, Sumter County, AL: (3) USNM 562457, holotype, aboral; (6) USNM 562457, detail of apical disc. Linthia alabamensis Clark, 1915: (5) MMNS 7164, aboral, from the McBryde Member, Clayton Formation, Palmyra tract, Lowndes County, AL; (7) MMNS 7354, aboral, from the Clayton Formation, Possum Grape, Jackson County, AR; (8) UF 278479, aboral, from the Pine Barren Member, Clayton Formation, Mussel Creek, Lowndes County, AL; (9) USNM 470904, holotype of Linthia maverickensis, aboral, from the Kincaid Formation, Maverick County, TX. Linthia tumidula Clark, 1891, from the Vincentown Formation, New Jersey: (10) AMNH 8954, lectotyope, aboral; (11) AMNH 8954, lectotype, posterior; (12) AMNH 8954, lectotype, profile. Scale bars are (1, 5, 7, 10-12) $20 \mathrm{~mm} ;(\mathbf{2}-\mathbf{4}) 10 \mathrm{~mm} ;(\mathbf{6}) 2 \mathrm{~mm} ;(\mathbf{8}, \mathbf{9}) 5 \mathrm{~mm}$. 
species is assigned to Diplodetus. A steinkern attributable to D. americanus (MMNS 5336) was collected from the Prairie Bluff Chalk at Prairie Bluff, Wilcox County, Alabama (UTM Zone 16, E 462,056 m, N 3,555,388 m, NAD83) and D. americanus is known from other Prairie Bluff Chalk localities in Mississippi, and is also reported from the Coon Creek Member of the Ripley Formation (Maastrichtian) in Tennessee (Ciampaglio and Phillips, 2016).

\section{Family Schizasteridae Lambert, 1905 Genus Linthia Desor, 1853}

Linthia alabamensis Clark, 1915

Figures 9.5, 9.7-9.9, 11.1-11.4, 13.1

1915 Linthia alabamensis Clark in Clark and Twitchell, p. 153, pl. 71, figs. 1a-d, 2a-d.

1933 Linthia maverickensis Gardner, p. 110, pl. 4, figs. 13, 14. 1942 Schizaster (Linthia) alabamensis; Cooke, p. 42.

1959 Linthia alabamensis; Cooke, p. 69, pl. 29, figs. 5-7.

1977 Linthia alabamensis; Toulmin, p. 178, pl. 9, fig. 5-7.

Type.-Holotype USNM 137371, from the Clayton Formation, Prairie Creek, Wilcox County, Alabama. Holotype of Linthia maverickensis USNM 370904.

Description.-Small to medium size, subcircular, wider than long, indented anteriorly and posteriorly; fairly tall, apex behind apical disc, oral surface flat and unkeeled, margins rounded. Apical disc ethmolytic, four genital pores, lateral pairs distinctly closer; plating variable but genital plate 4 usually occluded from genital 2 by posterior elongation of genital 3 (Fig. 11.1-11.3), sometimes not (Fig. 11.4). Ocular III deeply inserted, interambulacral plates $2 \mathrm{~b}$ and $3 \mathrm{a}$ occluded from ocular by ambulacral plates. Anterior ambulacrum depressed, shallowly near apical disc, but sulcus deepens towards anterior margin, then shallows to peristome; uniserial series of pore pairs, outer pores larger than inner, separated by single tubercle proximal to the ocular, tubercles lacking distally, very slightly oblique. Anterior petals straight to slightly flexed, diverge at $120^{\circ}-130^{\circ}$, somewhat wider in small (juvenile) specimens, posterior petals straight, about 80 percent length of anterior, diverge at $60^{\circ}$; interporiferous zones about as wide as poriferous, pores conjugate, elongate and unequal, outer pores larger. Periproct marginal, sloping forward and visible from above, taller than wide. Peristome reniform, lipped, in anterior quarter of test; labrum short, contacts sternal plates. Peripetalous fasciole deeply indented, parallels anterior petals for about three quarters of their length. Lateral fasciole branches near tips of anterior petals without offset. Tubercles small and densely spaced aborally, larger along margin of anterior ambulacrum; larger and less dense orally, with asymmetric areoles, posterior ambulacra naked.

Additional material.-MMNS 4504, Clayton Formation, Rockport, Hot Spring County, Arkansas, MMNS 7164, Clayton Formation, Palmyra tract, Lowndes County, Alabama, MMNS 7354, Clayton Formation, Possum Grape, Jackson County, Arkansas, NPL 4623, Kincaid Formation (Tehuacana Limestone), Kosse, Limestone County, Texas, UF 278479, UF 278480, UF 278481, Clayton Formation, Mussel Creek, Lowndes County, Alabama.
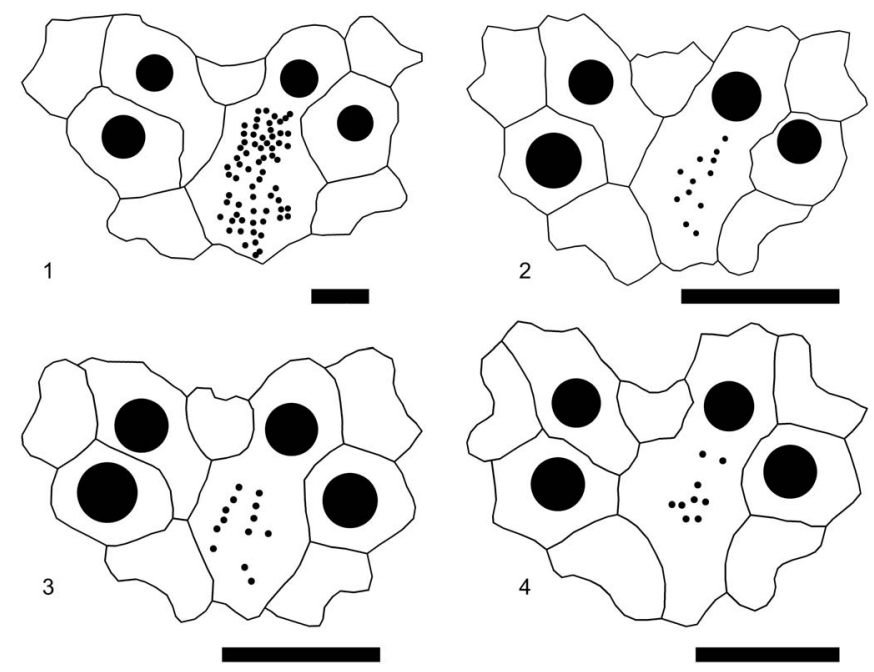

Figure 11. Linthia alabamensis Clark, 1915, apical disc plate patterns: (1) MMNS 7354, from the Clayton Formation, Possum Grape, Jackson County, AR; (2) UF278479, from the Pine Barren Member, Clayton Formation, Mussel Creek, Lowndes County, AL; (3) UF278480, from the Pine Barren Member, Clayton Formation, Mussel Creek, Lowndes County, AL; (4) UF278481, from the Pine Barren Member, Clayton Formation, Mussel Creek, Lowndes County, AL. Scale bars are $0.5 \mathrm{~mm}$.

Occurrence.-Clayton Formation, Prairie Creek, Wilcox County, Alabama (exact locality unknown). Kincaid Formation, Indio Ranch, Maverick County, Texas (exact locality unknown) (Type of L. maverickensis). Clayton Formation (McBryde Member), Resource Management Services Palmyra tract, west of State Highway 263, Butler and Lowndes County, Alabama (UTM Zone 16, E 525,183 m, N 3,539,105 m, NAD83). Clayton Formation (Pine Barren Member), Knights Road at Mussel Creek, Lowndes County, Alabama (UTM Zone 16, E 527,935 m, N 3,537,270 m, NAD83). Clayton Formation, beside Walmart, Rockport, Hot Spring County, Arkansas (UTM Zone 15, E 515,466 m, N 3,805,319 m, NAD83). Clayton Formation, Possum Grape, Jackson County, Arkansas (exact locality unknown). Clayton Formation, South Tippah Creek, west of State Highway 15, 1.75 miles north of Blue Mountain, Tippah County, Mississippi (UTM Zone 16, E $316,260 \mathrm{~m}$, N $3,841,071 \mathrm{~m}$, NAD83). Clayton Formation, excavations on State Highway 15, south of Ecru, Pontotoc County, Mississippi (UTM Zone 16, E 312,726 m, N 3,798,184 m, NAD83); Kincaid Formation (Tehuacana Limestone), quarry east side of County $\mathrm{Rd}$ 248, 0.5 mile south of State Highway 7, 5.25 miles west of Kosse, Falls County, Texas (UTM Zone 14, E 717,062 m, N 3,465,022 m, NAD83). Kincaid Formation (Tehuacana Limestone), pit south of State Highway 7, 12 miles east of Marlin, Falls County, Texas (UTM Zone 14, E 686,125 m, N 3,463,140 m, NAD83). Wills Point Formation, left bank of Dry Creek at confluence with Colorado River, 3 miles below Travis-Bastrop County line, Bastrop County, TX UTM Zone 14, E $647,011 \mathrm{~m}, \mathrm{~N} 3,340,004 \mathrm{~m}, \mathrm{NAD} 83)$. Other localities in Alabama and Arkansas (Clayton Formation) listed by (Cooke, 1959) and (Toulmin, 1977).

Remarks.-Description is expanded based on new material from Alabama, Arkansas, and Texas. The unequal lengths of the anterior and posterior petals (the posterior petals have an average plate count $\sim 74 \%$ that of the anterior petals) suggests 
that this species could be assigned to Schizaster rather than Linthia, but the structure of the apical disc is unlike that typically seen in Schizaster, and consideration of reassignment will require further study and evaluation of other related species.

Most morphological details of the type of Linthia maverickensis are obscured by matrix, but it does not differ substantially from other small specimens of L. alabamensis and on this basis the synonymy with $L$. alabamensis by Cooke (1942) is justified. Isolated occurrences of specimens substantially smaller than the type of L. alabamensis are found in Texas, Mississippi, and Alabama. Several lots in the UF collection, totaling several hundred specimens, were collected from the Pine Barren Member at the base of the Clayton Formation (early Danian) on Mussel Creek, Lowndes County, Alabama. The specimens range from $11-15 \mathrm{~mm}$ in length and are juveniles based on the poor development of the anterior sulcus, low total pore count in the petals, and reduced numbers of hydropores in the madreporite (Fig. 11.2-11.4), but all have fully developed genital pores and were apparently sexually mature. They are, in fact, very similar to specimens of $L$. variabilis (Slocum, 1909) collected from the Ripley Formation (Maastrichtian) at Pontotoc, Mississippi, although lacking the small tubercles or beads in the anterior ambulacrum characteristic of $L$. variabilis, and with more widely divergent petals. The in situ occurrence of these small L. alabamensis just above the Cretaceous/ Paleogene boundary suggests progenetic maturity in a population representing a recovery fauna.

Smith and Jeffery (2000) placed this species in synonymy with Paraster sindensis (Duncan and Sladen, 1882). The drawings in the original description are of little value in a comparison of the species, although the drawing of the plates of the apical disc indicates a similarly deep insertion of ocular plate III and occlusion of interambulacral plates $2 \mathrm{~b}$ and $3 \mathrm{a}$. The location of the holotype is not known but may be in the Duncan and Sladen collections of the Indian Museum, Kolkata. The specimen of $P$. sindensis figured by Jagt (2000) differs from L. alabamensis in the relative lengths of the petals, the deeper and narrower anterior sulcus, and the much less inflated outline and lack of shoulders in the posterior interambulacra.

Linthia tumidula Clark, 1891

Figures 9.10-9.12, 12.1, 12.4

1891 Linthia tumidula Clark, p. 77.

1893 Linthia tumidula; Clark, p. 91.

1907 Linthia tumidula; Weller, p. 304, pl. 18, figs. 1-9.

1915 Linthia tumidula; Clark in Clark and Twitchell, p. 99, pl. 53, figs. 1a-i.

1942 Schizaster (Linthia) tumidulus; Cooke, p. 41.

Types.-Lectotype AMNH 8954, from the Vincentown Formation, Vincentown, New Jersey. No holotype was designated by Clark (1891) or in any subsequent publications. Other cotypes indicated by Clark (in Clark and Twitchell, 1915) as residing in the Boston Society of Natural History and Johns Hopkins University collections are now missing.

Description.-Test oval to slightly cordiform, narrow anterior sulcus; base relatively flat, test tall, apex posterior of apical disc.
Apical disc ethmolytic, four equal-sized genital pores. Petals depressed, narrow, anterior pair longer than posterior and extending nearly to margin; pores conjugate, oval, nearly equal-sized. Anterior ambulacrum depressed, narrow; pores in two single series, individual pore pairs inset, separated by faint stereom wall. Anterior petals widely diverging $150^{\circ}$, posterior pair narrowly diverging $40^{\circ}$. Surface covered by fine primary tuberculation, tubercles larger on margin and oral surface, oral posterior ambulacra naked. Peristome transverse, reniform, lipped. Periproct small, oval, marginal, not visible from above. Peripetalous fasciole passes at tip of anterior petals and forms a distinct zig-zag pattern in the posterior paired interambulacra, meeting lateral fasciole such that the three shared angles all approach $120^{\circ}$.

Additional material.-USNM 488624, USNM 488772, USNM 540913, USNM 636364, all from the Vincentown Formation, Vincentown, New Jersey.

Occurrence.-Vincentown Formation, Vincentown, New Jersey (exact locality unknown).

Remarks.-Description expanded based on new material from New Jersey. Clark (in Clark and Twitchell, 1915) listed specimens in the American Museum of Natural History, the Boston Society of Natural History, and Johns Hopkins University. The AMNH has a specimen listed as a syntype and this is hereby designated as the lectotype. The Harvard Museum of Comparative Zoology, which received much of the Boston Society material, lists three specimens in the catalog (HMCZ IPEC-3941), but these were reportedly collected from Alabama, and are now lost. The Johns Hopkins collection was moved to the Smithsonian, but Cooke (1942) stated that no specimens were found in the NMNH collections, and that the type was in the AMNH. It was not included in the list of species from the Vincentown in Cooke (1959), but several previously unidentified specimens have been found in the collection. According to specimen labels, all of these were collected long after Clark's description of the species.

Linthia prima (Cooke, 1942)

Figure 12.7, 12.10-12.14

1942 Eupatagus? (Brissopatagus?) primus Cooke, p. 59, pl. 4, figs. 1-4.

1959 Linthia? prima; Cooke, p. 70, pl. 43, figs. 1-4.

2000 Linthia? prima; Smith and Jeffery, p. 335.

Type.-Holotype USNM 498978, from the Clayton Formation, 5 miles south of Ellaville, Schley County, Georgia.

Description.-Test cordate, medium size, upper surface high, posterior paired interambulacra form distinct shoulder near apex; oral surface relatively flat with slight posterior keel, margins sharply rounded. Broad, relatively deep anterior sulcus, indenting anterior margin. Apical disc nearly central, ethmolytic, four genital pores. Petals straight, in deep, broad depressions; anterior pair longer than posterior pair, anterior pair diverge at $120^{\circ}-140^{\circ}$, posterior pair diverge at $60^{\circ}$. Pore pairs in anterior ambulacrum 

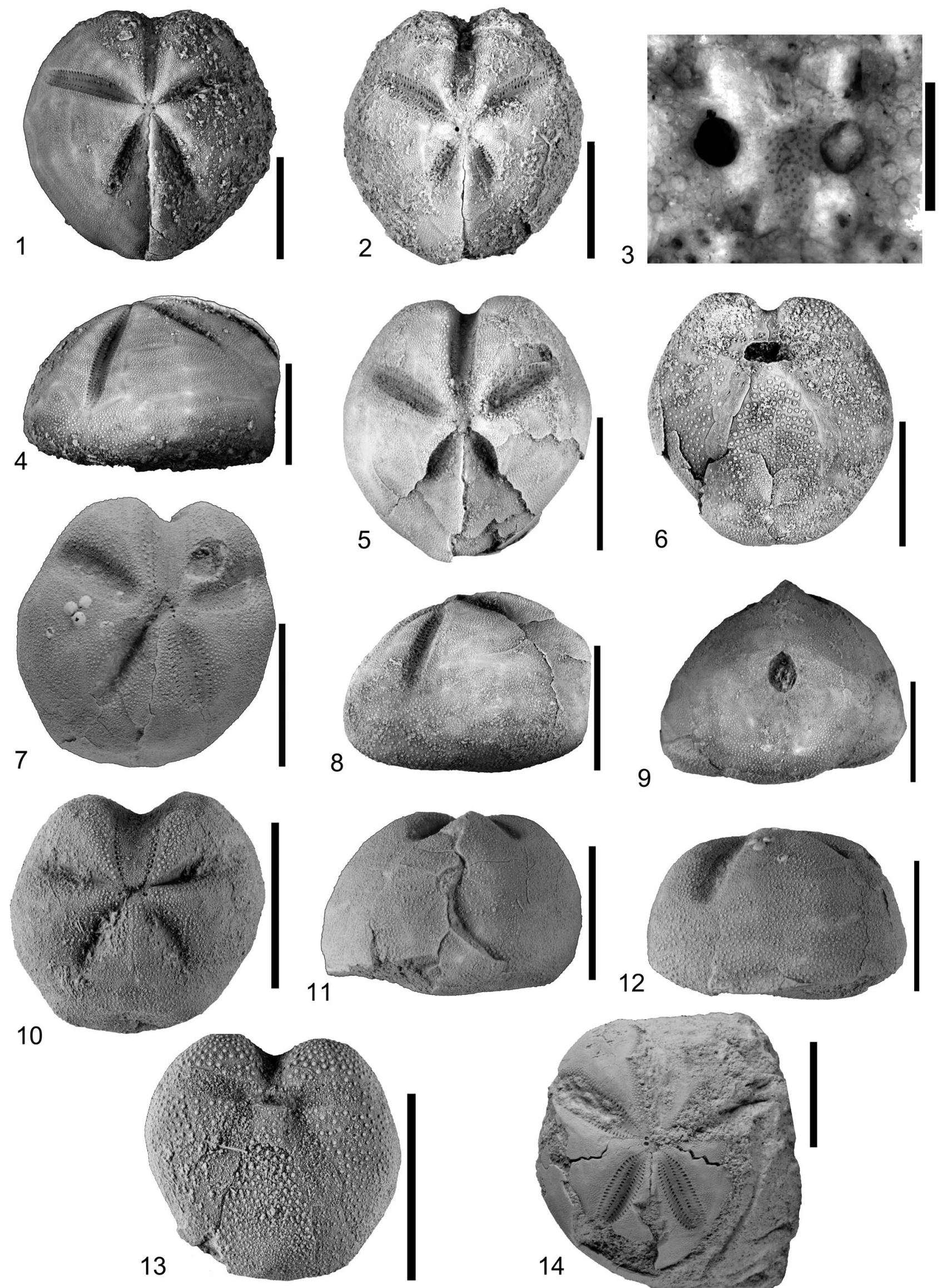

12

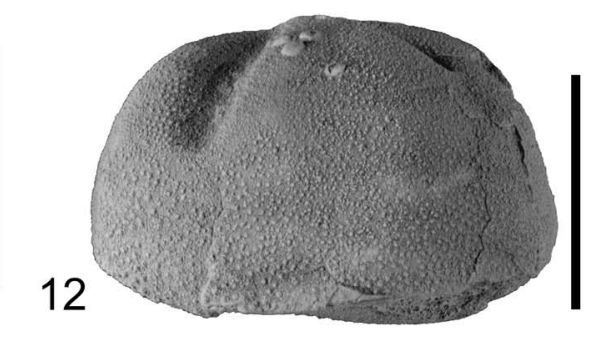


unequal, outside pore larger than interior, somewhat oblique, separated by small bead; replaced by single pores near margin, at least internally. Pores in petals elongate, conjugate, outer pores more elongate than inner. Peristome in anterior third of test, semicircular in outline, lipped. Labrum short, contacts both sternal plates. Peripetalous fasciole not deeply indented, parallel to anterior petal for about half their length, then straight to tips of posterior petals, lateral fasciole indistinct and poorly developed. Tubercles small aborally, larger along margins of ambulacral depressions; larger and more scattered orally; posterior ambulacra naked orally.

Additional material.-MMNS 5301, from the Clayton Formation, Lowndes County, Alabama. MMNS 7095, MMNS 7096.1, and MMNS 7096.2 from Clayton Formation, Shell Creek Park on Alabama River, Wilcox County, Alabama.

Occurrence.-Clayton Formation, Dr. A.J. Parkes farm, 5 miles south of Ellaville, Schley County, Georgia (exact locality unknown). Clayton Formation (McBryde Member), Resource Management Services Palmyra tract, west of State Highway 263, Butler and Lowndes County, Alabama (UTM Zone 16, E 525,183 m, N 3,539,105 m, NAD83). Clayton Formation (Pine Barren Member), Shell Creek Park on Alabama River at State Highway 28 (Millers Ferry), north of Camden, Wilcox County, Alabama (UTM Zone 16, E 461,710 m, N 3,553,196 m, NAD83).

Remarks.-Description is based on new material from Alabama. Although the type of Linthia prima is a steinkern (with a small amount silicified aboral test preserved), it is strongly characterized by the four genital pores, high anterior portion of the test, and pore patterning in the anterior ambulacrum. A number of schizasterid echinoid specimens agree closely in these details while differing significantly from other Linthia species in the collections. These are referred to L. prima, which is redescribed on the basis of this new material.

\section{Genus Ova Gray, 1825}

Ova rancoca new species

Figures $12.2,12.3,12.5,12.6,12.8,12.9,13.2$

Types.-Holotype USNM 540894, paratypes USNM 488623, USNM 488773, and USNM 636365, from the Vincentown Formation, Vincentown, Burlington County, New Jersey.

Diagnosis.- - Test oval, slightly cordiform; tallest behind apical disc. Apical disc nearly central, ethmolytic, two large genital pores. Anterior ambulacrum in deep, narrow sulcus, petals straight, in deep, narrow depressions, anterior petals longer than posterior. Peripetalous fasciole deeply indented; lateral fasciole branches from peripetalous fasciole after it bends inward from tip of petal to form a distinct offset.

Description.-Test oval, slightly cordiform; tallest behind apical disc, sloping towards anterior to a greater or lesser degree, posterior interambulacral plates form distinct ridge along meridional suture; oral surface slightly convex, with little or no keel. Apical disc nearly central, ethmolytic, two large genital pores, anterior genital plates imperforate. Anterior ambulacrum in deep, narrow sulcus, pore pairs unequal, outer pore largest, inner pores vestigial. Petals straight, in deep, narrow depressions, anterior petals two and a half times longer than posterior, anterior pair diverge at $120^{\circ}$, posterior pair at $55^{\circ}-60^{\circ}$; pores elongate, conjugate, nearly equal in size; interporiferous zones narrower than poriferous zones. Periproct marginal, vertical, taller than wide. Peristome in anterior third of test, oval, wider than tall, no apparent lip. Labrum small and short, contacts sternal plates. Sternal plates large, about two-thirds of test length. Large phyllode pores surrounding peristome. Peripetalous fasciole deeply indented, parallels anterior petal for three quarters of its length, crosses above periproct near apex; lateral fasciole branches from peripetalous fasciole on interambulacral plate 5 after it bends inward from tip of petal to form a distinct offset (Fig. 13.2). Tubercles small aborally, larger along margin of anterior ambulacrum; larger and more scattered orally, with asymmetric areoles in paired interambulacra; posterior ambulacra naked orally.

Etymology.-Named for Rancocas Creek, source of much of the Vincentown material.

Occurrence.-Vincentown Formation, Rancocas Creek, Vincentown, Burlington County, New Jersey (UTM Zone 18, E 520,995 m, N 4,421,446 m, NAD83).

Remarks.-Superficially resembles Linthia alabamensis (Clark, 1915), but readily distinguished by two rather than four genital pores and the distinctive offset branching of the peripetalous and lateral fascioles (Fig. 13.2) as compared with L. alabamensis (Fig. 13.1). The posterior petals of $O$. rancoca n. sp. are proportionately shorter than those of L. alabamensis.

\section{Discussion}

Smith and Jeffery (2000) pointed out the need for careful taxonomic treatment based on informative morphologic characters. In this study, revision of taxonomy as well as study of undescribed material has led to retention of several names synonymized by Smith and Jeffery (2000) and thus a higher degree of splitting of species than that employed by them. In particular, a distinction is made between European (and African) species and those of North America. It has long been noted (Gregory, 1892; Stefanini, 1924) that the fossil record of the early Cenozoic indicates significant

Figure 12. Linthia tumidula Clark, 1891 from the Vincentown Formation, New Jersey (exact locality unknown): (1) USNM 488624, aboral; (4) USNM 488624, profile. Ova rancoca n. sp. from the Vincentown Formation, Vincentown, Burlington County, NJ: (2) USNM 636365, paratype, aboral; (3) USNM 636365, paratype, detail of apical disc; (5) USNM 540894, holotype, aboral; (6) USNM 540894, holotype, oral; (8) USNM 540894, holotype, profile; (9) USNM 488623, paratype, posterior. Linthia prima (Cooke, 1942) from the Pine Barren Member, Clayton Formation: (7) MMNS 7095, aboral, Shell Creek Park, Wilcox County, AL; (10) MMNS 7096.1, aboral, Shell Creek Park, Wilcox County, AL; (11) MMNS 7095, posterior, Shell Creek Park, Wilcox County, AL; (12) MMNS 7095, profile, Shell Creek Park, Wilcox County, AL; (13) MMNS 7096.1, oral, Shell Creek Park, Wilcox County, AL; (14) MMNS 5301, aboral, McBryde Member, Clayton Formation, Palmyra Tract, Lowndes County, AL. Scale bars are (1, 2, 4-14) $20 \mathrm{~mm} ;(\mathbf{3}) 2 \mathrm{~mm}$. 

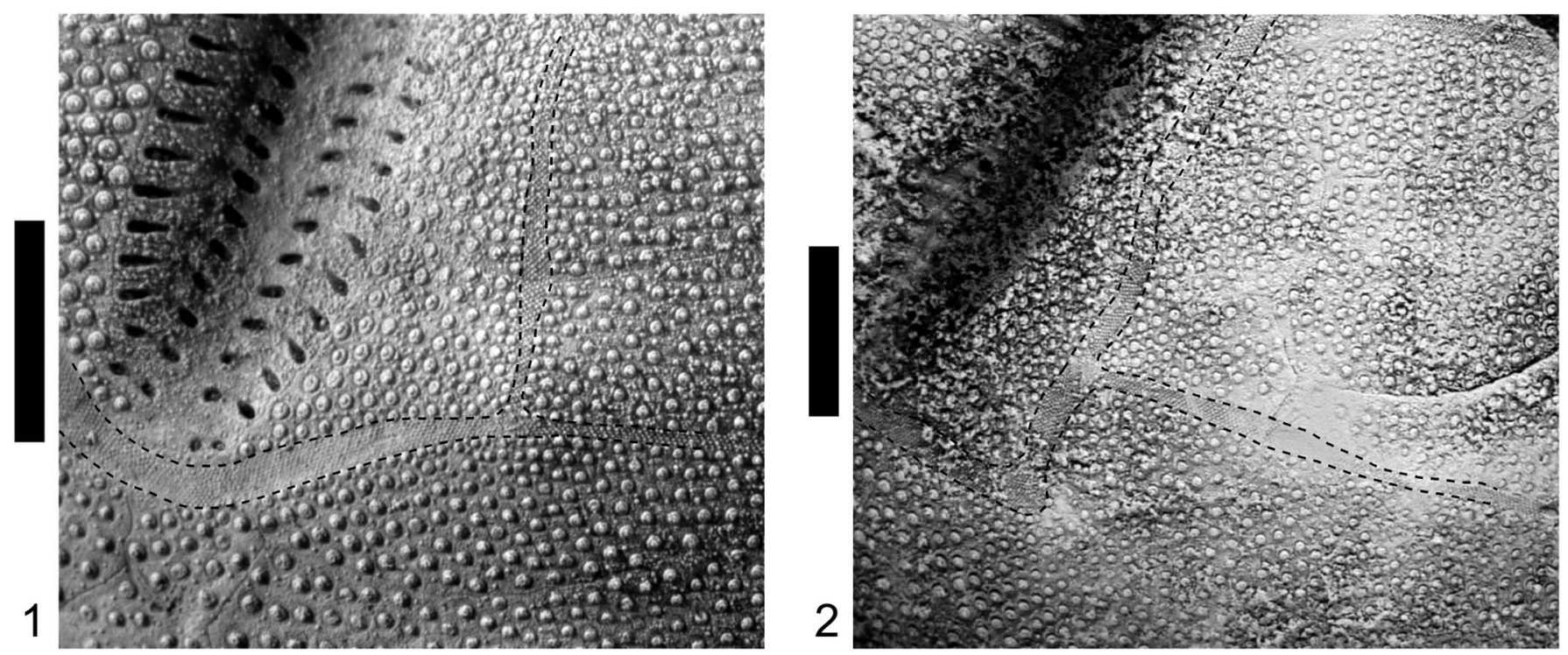

Figure 13. Comparison of the junctions of the peripetalous and lateral fascioles (outlined) in (1) Linthia alabamensis Clark, 1915, MMNS 7164, from the McBryde Member, Clayton Formation, Palmyra Tract, Lowndes County, AL and (2) Ova rancoca n. sp., holotype, USNM 540894, from the Vincentown Formation, Vincentown, Burlington County, NJ. Scale bars are $5 \mathrm{~mm}$.

migration of echinoid genera from east to west across the Atlantic Ocean, but rarely in the other direction. The expectation is that while there may be genera common to both the eastern and western hemispheres, it is probable that genetic drift would rapidly split any immigrant species in North America into separate clades. The expanding Atlantic Ocean basin was likely a significant biotic barrier at the beginning of the Paleocene, becoming more so over time.

Nearly all of the echinoid occurrences in the eastern North American Paleocene are in carbonate rocks. These are generally coarse-grained, and in the case of the Vincentown Formation (Thanetian) in New Jersey and the Clayton Formation (Danian) exposed in western Georgia and eastern Alabama comprise bryozoan and coralline algal debris. The fault-bound exposure of Salt Mountain Limestone (Thanetian) in Alabama represents a coral reef buildup, although the echinoids (mostly spines and test fragments) are found in the detrital fore-reef deposits. What paleoecological differentiation there is between the southern faunas of the Gulf Coast (mostly Danian) and the northern faunas of the Atlantic Coast (Thanetian) is obscured by the differences in age. Furthermore, the lack of any definite Selandian echinoid occurrences in eastern North America inhibits any study of the transition between these two main faunal groups of echinoids. Finally, although echinoids are common at a very few local sites, these occurrences are generally monospecific, and echinoids are rare overall from these Paleocene rocks and not often found in situ. This has proven a serious impediment to paleoecologic studies. What is clear is that the Danian in the Gulf Coast region represents a period of faunal recovery following the catastrophic end of the Cretaceous, an effect perhaps enhanced by proximity to the Chicxlub impact, which is emphasized by the low diversity and paucity of the echinoid fauna. One aspect of the diversity indicative of recovery is that the majority of the species are epibenthic (or semi-infaunal) forms, either regular urchins, or irregular urchins, lacking fascioles, whose modern representatives are epibenthic. Paleocene carbonate platforms were dominated by bryozoan and coralgal communities (Scheibner and Speijer, 2008), and Kroh (2001, 2003) noted a preference of epibenthic forms from the Danian of Austria for coralline-algae dominated carbonate environments and a similar preference could be at play in the faunas studied here.

\section{Acknowledgments}

I am indebted to G. Phillips, Mississippi Museum of Natural Science, Jackson, MS, for loan of material, arrangement and logistic support of collecting trips, and for many discussions regarding the geology and paleontology of the Gulf Coast. I would like to thank K. Lucker, Resource Management Services, Greenville, AL for access to Palmyra property; C. Gardner, Waste Management of Mississippi, Houston, MS for access to the Prairie Bluff Landfill; C. Swann and G. Martin for donation of specimens; C. Garvie for loan of specimens. I also thank R. Portell, Florida Museum of Natural History; A. Molineux, Non-Vertebrate Paleontology Laboratory, University of Texas; and D. Levin, M. Florence, and K. Hollis, U. S. National Museum of Natural History for their help with and access to collections. P. Calloman, Academy of Natural Sciences of Drexel University, Philadelphia for information on types. M. Hopkins and B. Hussaini, American Museum of Natural History, supplied the photographs of the lectotype of Linthia tumidula. Finally, I would like to thank A. Kroh and an anonymous reviewer for many comments that substantially improved the manuscript.

\section{References}

Agassiz, L., 1838-1842, Monographies d'Échinodermes Vivans et Fossiles: Neuchâtel, aux frais de l'auteur, Petitpierre, $621 \mathrm{p}$.

Agassiz, L., 1840, Catalogus systematicus ectyporum echinodermatum fossilium Musei Neocomensis, secundum ordinem zoologicum dispositus; adjectis synonymis recentioribus, nec non stratis et locis in quibus reperiuntur. Sequuntur characteres diagnostici generum novorum vel minus cognitorum: Solothurn, Oliv. Petitpierre, 20 p. 
Agassiz, L., and Desor, E., 1847, Catalogue raisonné des familles, des genres et des espèces de la classe des échinodermes 1: Annales des Sciences Naturelles, ser. 3, v. 7, p. 129-168.

Barry, J.O., and Le Blanc, R.J., 1942, Lower Eocene faunal units of Louisiana: Louisiana Geological Survey Geological Bulletin, v. 23, 208 p.

Berggren, W.A., and Pearson, P.N., 2005, A revised tropical to subtropical Paleogene planktonic foraminiferal zonation: Journal of Foraminiferal Research, v. 35, p. 279-298.

Bronn, H.G., 1851-1852, Lethaea Geonostica: Stuttgart, E. Schweizerbart, v. 2, pt. $5,412 \mathrm{p}$

Bybell, L.M., 1992, Calcareous nannofossils-Their use in interpreting Paleocene and Eocene geologic events in the New Jersey coastal plain, in Gohn, G.S., ed., Proceedings of the 1988 U.S. Geological Survey Workshop on the Geology and Geohydrology of the Atlantic Coastal Plain: U.S., Geological Survey Circular, v. 1059, p. 9-13.

Carter, B.D., 1997, The Salt Mountain Limestone of Alabama, Part VI, Echinoids: Tulane Studies in Geology and Paleontology, v. 30, p. 44-52.

Ciampaglio, C.N., and Phillips, G.E., 2016, Irregular echinoids of the Upper Cretaceous Coon Creek beds in Tennessee, in Ehret, D, Harrell, T.L., and Ebersole, S., eds., Paleontology of the Cretaceous Coon Creek Formation: Alabama Museum of Natural History Bulletin 33, v. 2, p. 59-77.

Clark, H.L., 1917, Hawaiian and other Pacific Echini. The Echinoneidae, Nucleolitidae, Urechinidae, Echinocorythidae, Calymnidae, Pourtalweiidae, Paleostomatidae, Aeropsidae, Paleopneustidae, Hemiasteridae, and Spatangidae: Museum of Comparative Zoology at Harvard College Memoirs, v. 2, p. 85-283.

Clark, W.B., 1891, A revision of the Cretaceous Echinoidea of North America: Johns Hopkins University Circulars, v. 10, p. 75-77.

Clark, W.B., 1893, The Mesozoic Echinodermata of the United States: U.S. Geological Survey Bulletin, v. 97, 207 p.

Clark, W.B., and Twitchell, M.W., 1915, The Mesozoic and Cenozoic Echinodermata of the United States: U.S. Geological Survey Monograph, $341 \mathrm{p}$.

Claus, C.F.W., 1880, Grundzüge der Zoologie: Marburg and Leipzig, N. G. Elwert'sche Universitätsbuchhandlung, $522 \mathrm{p}$.

Cooke, C.W., 1941, Cenozoic regular echinoids of eastern United States: Journal of Paleontology, v. 15, p. 1-20.

Cooke, C.W., 1942, Cenozoic irregular echinoids of eastern United States: Journal of Paleontology, v. 16, p. 1-62.

Cooke, C.W., 1959, Cenozoic echinoids of eastern United States: U.S. Geological Survey Professional Paper, v. 321, 106 p.

Cope, K.H., Utgaard, J.E., Masters, J.M., and Feldmann, R.M., 2005, The fauna of the Clayton Formation (Paleocene, Danian) of southern Illinois: a case of K/P survivorship and Danian recovery: Bulletin of the Mizunami Fossil Museum, v. 32, p. 97-108.

Cotteau, G., 1864, Description des Animaux Invertébrés Commencée par Alcide D’Orbigny, Terrain Crétacé, Échinides: Paris, V. Masson, v. 7, 892 p.

d'Orbigny, A.D., 1850, Prodrome de paléontologie stratigraphique universelle des animaux mollusques \& rayonnés: Paris, V. Masson, v. 2, 427 p.

d'Orbigny, A.D., 1853-1856, Paléontologie Française. Terrains Crétacés. Échinodermes: Paris, V. Masson, 598 p.

d'Orbigny, A.D., 1854, Note rectificative sur divers genres d'Echinoïdes: Revue et Magasin de Zoologie Pure et Appliquée, sér. 2, v. 6, p. 16-28.

Davidoff, A.J., and Yancey, T.E., 1993, Eustatic cyclicity in the Paleocene and Eocene: data from the Brazos River Valley: Texas, Tectonophysics, v. 222, p. 371-395.

Delage, Y., and Hérouard, E., 1903, Les Échinodermes: Paris, Schleicher Frères Traité de Zoologie Concrète, $496 \mathrm{p}$

Desor, E., 1853, Notice sur les échinides du terrain nummulitique des Alpes, avec les diagnoses de plusieurs espèces et genres nouveaux: Actes de la Société Helvétique des Sciences Naturelles, v. 38, p. 270-279.

Desor, E., 1858, Synopsis des Échinides Fosiles: Paris, Reinwald, 490 p.

Duncan, P.M., 1889, A revision of the genera and great groups of the Echinoidea: The Journal of the Linnaean Society, Zoology, v. 23, 311 p.

Duncan, P.M., and Sladen, M.T.P., 1882, A description of the fossil echinoidea of Western Sind: Palaeontologia Indica, ser. 14, v. 1, no. 3, p. 1-20.

Durham, J.W., and Melville, R.V., 1957, A classification of echinoids: Journal of Paleontology, v. 31, p. 242-272.

Gabb, W.M., 1859, Catalogue of the invertebrate fossils of the Cretaceous formation of the United States: Proceedings of the Academy of Natural Sciences of Philadelphia, v. 1859, p. 1-20.

Gardner, J., 1933, The Midway Group of Texas: University of Texas Bulletin $3301,403 \mathrm{p}$

Gauthier, V., 1889, Description des échinides fossiles recuellis en 1885 et 1886 dans la région sud des Hauts-Plateaux de la Tunisie par M. Phillipe Thomas: Exploration scientifique de la Tunise, Paris, Imprimerie National, $116 \mathrm{p}$.

Gray, J.E., 1825, An attempt to divide the Echinida, or sea eggs, into natural families: The Annals of Philosophy, v. 10, New Series, p. 423-431.

Gray, J.E., 1835, On the genera distinguishable in Echinus Lamarck: Proceedings of the Zoological Society of London, v. 3, p. 57-60.
Gray, J.E., 1855, An arrangement of the families of Echinida, with description of some new genera and species: Proceedings of the Zoological Society of London, v. 23, p. 35-39.

Gregory, J.W., 1892, The relations of the American and European echinoid faunas: Geological Society of America Bulletin, v. 3, p. 101-108.

Gregory, J.W., 1900, The Echinoidea, in Lankester, E.R., ed., A Treatise on Zoology: Part III The Echinoderma: London, Adam \& Charles Black, p. 282-332.

Hennig, A., 1898, Faunan i Skånes Yngre Krita. I. Echiniderna: Bihang till Kongliga Svenska Vetenskaps-Akademiens Handlingar, v. 24, p. 3-12.

Hinz, R., 1985, Die paläarktischen Arten der Gattung Trematopygus Holmgren: Spixiana, v. 8, p. $265-276$

Holmgren, A.E., 1858, Försök till uppställning och beskrifning af de i Sverige funna tryphonider; Monographia Tryphonidum Sueciae: Kongliga Svenska Vetenskaps-Akademiens Handlingar, NF 1, p. 93-246.

Ikeda, H., 1936, Preliminary note on a new family of the Cidaroidea: Annotationes Zoologicae Japonenses, v. 15, p. 486-493.

Jagt, J.W.M., 2000, Late Cretaceous-Early Palaeogene echinoderms and the $\mathrm{K} / \mathrm{T}$ boundary in the southeast Netherlands and northeast Belgium-Part 4: Echinoids: Scripta Geologica, v. 121, p. 181-375.

Kier, P.M., 1962, Revision of the Cassiduloid echinoids: Smithsonian Miscellaneous Collections, v. 144, no. 3, 262 p.

Kroh, A., 2001, Echinoids from the Danian (Lower Paleocene) Brunderndorf Formation of Austria, in Piller, W.E., and Rasser, M.W., eds., Paleogene of the Eastern Alps: Österreichische Akademie der Wissenschaften, Schriftenreihe der Erdwissenschaftlichen Kommission, v. 14, p. 377-463.

Kroh, A., 2003, Palaeobiology and biogeography of a Danian echinoid fauna of Lower Austria, in Féral, J., and David, B., eds., Echinoderm Research 2001: Lisse, Swets and Zeitlinger, p. 69-75.

Kroh, A., Madeira, P., and Haring, E., 2012, Species distributions: virtual or realthe case of Arbaciella elegans (Echinoidea: Arbaciidae): Journal of Zoological Systematics and Evolutionary Research, v. 50, p. 99-105.

Lambert, J., 1888, Note sur un nouveau genre d'échinidae de la Craie de l'Yonne: Bulletin de la Société des Sciences Historiques et Naturelles de l'Yonne, sér 3, v. 11, p. 3-14.

Lambert, J., 1905, Echinides, in Doncieux, L., ed., Catalogue descriptif des fossiles nummulitiques de l'Aude et de l'Hérault: Annales de l'Université de Lyon, Nouvelle Série, I. Sciences, Médecine, v. 17, 184 p.

Lambert, J., 1920, Sur quelques genres nouveaux d'échinides: Mémoires de la Société Académique d'Agriculture des Sciences, Arts et Belles-Lettres du Département de l'Aube, v. 57, p. 145-172.

Lambert, J., and Thiéry, P., 1911, Essai de Nomenclature Raisonnée des Échinides: Paris, Chaumont, v. 3, p. 161-240.

Lambert, J., and Thiéry, P., 1921, Essai de Nomenclature Raisonnée des Échinides: Paris, Chaumont, v. 5, p. 321-384.

Lambert, J., and Thiéry, P., 1924, Essai de Nomenclature Raisonnée des Échinides: Paris, Chaumont, v. 6 and 7, p. 385-512.

Lambert, J., and Thiéry, P., 1925, Essai de Nomenclature Raisonnée des Échinides: Paris, Chaumont, v. 8 and 9, p. 513-607.

Lauginiger, E.M., 1988, Cretaceous fossils from the Chesapeake and Delaware Canal: Delaware Geological Survey Special Publication 18, 56 p.

Leske, N.G., 1778, Iacobi Theodori Klein Naturalis Dispositio Echinodermatum: Accesserunt Lucubratiuncula de Aculeis Echinorum Marinorum et Spicilegium de Belemnitis: Ex Officina Gleditschiana, Lipsiae, 278 p.

Lovén, S., 1874, Études sur les Échinoïdées: Kongliga Svenska VetenskapsAkademiens Handlingar, v. 11, no. 7, 91 p.

Mancini, E.A., and Tew, B.H., 1991, Relationships of Paleogene stage and planktonic foraminiferal zone boundaries to lithostratigraphic and allostratigraphic contacts in the eastern Gulf Coastal Plain: Journal of Foraminiferal Research, v. 21, p. 48-66.

Martínez-Díaz, J.L., Phillips, G.E., Nyborg, T., Espinosa, B., Távora, V.d.A., Centeno-García, E., and Vega, F.J., 2016, Lilliput effect in a retroplumid crab (Crustacea: Decapoda) across the K/Pg boundary: Journal of South American Earth Sciences, v. 69, p. 11-24.

Melville, R.V., 1952, On a new species of irregular echinoid (Plagiochasma coxwellense sp. nov.) from the Lower Greensand of Faringdon: Berks., Bulletin of the Geological Survey of Great Britain, v. 4, p. 1-7.

Mortensen, T., 1904, The Danish Expedition to Siam 1899-1900 II. Echinoidea (I): Mémoires de l'Académie Royale des Sciences et Lettres de Danemark, Copenhague, sér. 7, v. 1, p. 1-124.

Mortensen, T., 1910, Arbaciella elegans. Eine neue Echiniden-Gattung aus der Familie Arbaciidae: Mitteilungen des Naturhistorischen Museum Hamburg, v. 27, p. $327-334$

Mortensen, T., 1928, I. Cidaroidea, A Monograph of the Echinoidea: Copenhagen, C.A. Reitzel, 551 p.

Mortensen, T., 1935, II. Bothriocidaroida, Melonechinoida, Lepidocentroida, and Stirodonta, A Monograph of the Echinoidea: Copenhagen, C.A. Reitzel, 647 p.

Mortensen, T., 1942, New echinoidea (Camarodonta). Preliminary notice: Videnskabelige Meddelelser fra Dansk Naturhistorisk Forening i Kjøbenhavn, v. 106, p. 225-232. 
Morton, S.G., 1830a, Synopsis of the organic remains of the ferruginous sand formation of the United States, with Geological Remarks: American Journal of Science, ser. 1, v. 18, p. 243-250.

Morton, S.G., 1830b, Additional observations on the geology and organic remains of New Jersey and Delaware: Journal of the Academy of Natural Sciences of Philadelphia, ser. 1, v. 6, part 1, p. 189-204.

Morton, S.G., 1833, Supplement to the "Synopsis of the organic remains of the ferruginous sand formation of the United States": American Journal of Science, ser. 1, v. 23, p. 288-294.

Morton, S.G., 1834, Synopsis of the organic remains of the Cretaceous Group of the United States: Philadelphia, Key \& Biddle, 98 p.

Morton, S.G., 1841, Stated Meeting, Written Communications: Academy of Natural Sciences of Philadelphia Proceedings, v. 1, p. 131-133.

Morton, S.G., 1842, Description of some new species of organic remains of the Cretaceous Group of the United States: with a tabular view of the fossils hitherto discovered in this formation: Journal of the Academy of Natural Sciences of Philadelphia, v. 8, p. 207-215.

Pictet, F.J., 1857, Traité de Paléontologie: Paris, J. Bailliére, 768 p.

Pomel, A., 1869, Revue des Échinodermes et leur classification pour servir d'introduction á l'étude des fossiles: Paris, C. Deyrolle, $67 \mathrm{p}$

Pomel, A., 1883, Classification Mèthodique et Genera des Échinides Vivants et Fossiles, [Doctoral thesis]: Academie de Paris, $131 \mathrm{p}$.

Ravenel, E., 1850, On the Recent Squalidae of the coast of South Carolina, and a catalogue of the Recent and fossil echinoderms of Carolina: Proceedings of the American Association for the Advancement of Science, v. 3, p. 159-161.

Rose, E.P.F., 1982, Holectypoid echinoids and their classification, in Lawrence, J.M., ed., International Echinoderm Conference: Tampa Bay, A.A Balkema, p. 145-152.

Scheibner, C., and Speijer, R.P., 2008, Late Paleocene-early Eocene Tethyan carbonate platform evolution-A response to long- and short-term paleoclimatic change: Earth-Science Reviews, v. 90, p. 71-102.

Schlüter, C., 1900, Ueber einige Kreide-Echiniden: Zeitschrift der Deutschen Geologischen Gesellschaft, v. 52, p. 360-279.

Sherwood, C.D., 1899, On the dates of the "Paléontologie Française" of d'Orbigny: Geological Magazine, n. ser. 10, v. 6, p. 223-225.

Slocum, A.W., 1909, New echinoids from the Ripley group of Mississippi: Field Museum of Natural History Publication 134, $16 \mathrm{p}$.

Smith, A.B., and Jeffery, C.H., 2000, Maastrichtian and Palaeocene echinoids: a key to world faunas: The Palaeontological Association Special Papers in Palaeontology, $406 \mathrm{p}$.
Smith, A.B., and Kroh, A., 2011, The Echinoid Directory: http://www.nhm.ac.uk/ research-curation/projects/echinoid-directory (accessed February 4, 2017).

Smith, E.A., 1910, Cretaceous-Eocene Contact: Tombigbee River, Alabama: The Journal of Geology, v. 18, p. 430-434.

Smith, E.A., Johnson, L.C., and Langdon, D.W. Jr., 1894, Report on the Geology of the Coastal Plain of Alabama: Tuscaloosa, Geological Survey of Alabama, $759 \mathrm{p}$.

Stefanini, G., 1924, Relations between American and European Tertiary echinoid faunas: Bulletin of the Geological Society of America, v. 35, p. $827-846$.

Stephenson, L.W., 1915, The Cretaceous-Eocene contact in the Atlantic and Gulf coastal plain: U.S. Geological Survey Professional Paper 90, p. 155-182.

Stephenson, L.W., 1941, The larger invertebrate fossils of the Navarro Group of Texas: University of Texas Publication 4101, 641 p.

Toulmin, L.D., 1977, Stratigraphic distribution of Paleocene and Eocene fossils in the eastern Gulf Coast region: Geological Survey of Alabama Monograph $13,602 \mathrm{p}$.

Walker, J.D., Geissman, J.W., Bowring, S.A., and Babcock, L.E., and compilers 2012, GSA Geologic Time Scale v. 4.0: Geological Society of America, 1 p

Ward, L.W., and Powars, D.S., 1989, Tertiary stratigraphy and paleontology, Chesapeake Bay region, Virginia and Maryland: Washington, D.C., 28th International Geological Congress, $64 \mathrm{p}$.

Weller, S., 1907, A report on the Cretaceous paleontology of New Jersey: Geological Survey of New Jersey Paleontology Series 4, 871 p.

Wright, T., 1856, A monograph on the British fossil Echinodermata of the Oolitic Formations. Part second containing the Diademadae, Echinidae, Saleniadae, and Echinoconidae: Palaeontographical Society Monographs, v. 10, p. 155-303.

Zachos, J., Pagani, M., Sloan, L., Thomas, E., and Billups, K., 2001, Trends, rhythms, and aberrations in global climate $65 \mathrm{Ma}$ to present: Science, v. 292 , p. $686-693$.

Zachos, L.G., 2008, Preservation of echinoid fossils, Paleocene and Eocene of Texas: Gulf Coast Association of Geological Societies Transactions, v. 58, p. 919-932.

Zachos, L.G., and Levin, D., 2010, Rediscovery of figured Paleogene echinoid specimens from Clark and Martin (1901): Journal of Paleontology, v. 84, p. 148.

Accepted 28 March 2017 